\title{
Smart Asset Management for District Heating Systems in the Baltic Sea Region
}

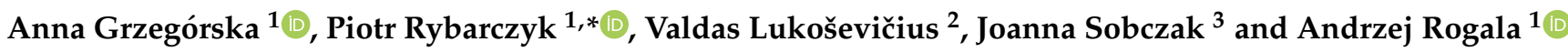 \\ 1 Department of Process Engineering and Chemical Technology, Faculty of Chemistry, Gdansk University of \\ Technology, Narutowicza 11/12 Street, 80-233 Gdansk, Poland; anna.grzegorska@pg.edu.pl (A.G.); \\ andrzej.rogala@pg.edu.pl (A.R.) \\ 2 Department of Energy, Faculty of Mechanical Engineering and Design, Kaunas University of Technology, \\ 51424 Kaunas, Lithuania; valdas.lukosevicius@ktu.edu \\ 3 Research and Development Joanna Sobczak, Różnowo 8, 14-240 Susz, Poland; joasobczak@outlook.com \\ * Correspondence: piotr.rybarczyk@pg.edu.pl
}

Citation: Grzegórska, A.; Rybarczyk, P.; Lukoševičius, V.; Sobczak, J.; Rogala, A. Smart Asset Management for District Heating Systems in the Baltic Sea Region. Energies 2021, 14, 314. https://doi.org/10.3390/ en14020314

Received: 17 December 2020 Accepted: 6 January 2021 Published: 8 January 2021

Publisher's Note: MDPI stays neutral with regard to jurisdictional clai$\mathrm{ms}$ in published maps and institutional affiliations.

Copyright: $\odot 2021$ by the authors. Licensee MDPI, Basel, Switzerland. This article is an open access article distributed under the terms and conditions of the Creative Commons Attribution (CC BY) license (https:// creativecommons.org/licenses/by/ $4.0 /)$.

\begin{abstract}
The purpose of this review is to provide insight and a comparison of the current status of district heating (DH) systems for selected Baltic Sea countries (Denmark, Germany, Finland, Latvia, Lithuania, Poland, and Sweden), especially from viewpoints of application and solutions of novel smart asset management (SAM) approaches. Furthermore, this paper considers European projects ongoing from 2016, involving participants from the Baltic Sea Region, concerning various aspects of DH systems. The review presents the energy sources with particular attention to renewable energy sources (RES), district heating generations, and the exploitation problems of DH systems. The essential point is a comparison of traditional maintenance systems versus SAM solutions for optimal design, operating conditions, and controlling of the DH networks. The main conclusions regarding DH systems in Baltic Sea countries are commitment towards a transition to 4th generation $\mathrm{DH}$, raising the quality and efficiency of heat supply systems, and simultaneously minimizing the costs. The overall trends show that applied technologies aim to increase the share of renewable energy sources and reduce greenhouse gas emissions. Furthermore, examples presented in this review underline the importance of the implementation of a smart asset management concept to modern DH systems.
\end{abstract}

Keywords: Baltic Sea Region; district heating; DH network; smart asset management; smart grid

\section{Introduction}

The district heating sector constitutes an important segment of energy generation in all developed countries. The history of district heating (DH) systems starts in the 19th century when so-called 1st generation DH systems were introduced, based on the combustion of coal for steam generation. Together with industrial devolvement, district heating systems have been undergoing a transition from using fossil fuels as heat sources towards a continuously rising share of renewable, solar, and geothermal energy sources. Parallel to the development of heat generation systems, heat distribution systems, as well as their maintenance techniques, have been modernized and improved. One of the most important milestones in the management of DH systems was the introduction of pre-insulated pipelines coupled with electric wires connected to alarm systems, which enabled the monitoring of damage in the DH system. In fact, the damage to heat distribution systems, related mainly to the aging of the infrastructure, is posing the biggest social and economic threat related to the exploitation of DH systems. What is more, old infrastructure, e.g., channel pipes with damaged insulation, leads to heat losses, affecting the economy and efficiency of heat distribution. Thus, further development of modern and reliable management systems, allowing for the prediction of possible failures as well as the application of novel durable 
materials and solutions during the installation of new DH networks, are crucial factors determining their safe, reliable, and long-term exploitation.

Assuring the safety of heat distribution is a legal requirement resulting from energetic policies in all modern countries. Safe and reliable usage of such networks, from the perspective of the consumer, means the lowest possible number of incidents leading to interruption in the heat supply. From the perspective of DH systems' owners, reliable, safe, and efficient networks are those without heat loss and unexpected damage, as well as those that ensure possible high incomes. In order to ensure the implementation of such an approach, so-called smart asset management (SAM) methods need to be considered. By definition, smart asset management is an approach to maintenance via control, prediction, optimization, and selective refurbishment of assets with the aid of novel hardware and software solutions. The SAM approach is universal, e.g., it may be applied in the transportation sector [1]; however, it is well suited to the management of district heating systems. Nowadays, the SAM concept in the DH sector is in the early stage of research and development. However, in the next few years, DH systems are likely to become smart grids. According to Gao et al. [2], smart DH has more prominent benefits than the traditional $\mathrm{DH}$ system in numerous aspects, i.e., energy savings or troubleshooting, therefore it has high expansion potential and broad market perspectives in the future. Smart thermal grids, corresponding to smart electricity grids, exploit the potential of renewable energy sources (RES), thermal energy storage (TES), and prosumers and bi-directional networks, as well as the integration of intelligent management [3-5]. Smart heating and cooling use algorithm and model-based control methods. Currently, the SAM methods in DH mainly concern predictive control of the network, including forecasting of heat consumption and thermal comfort optimization [6,7]. Furthermore, smart optimization of pipe dimensions, insulation, and pipeline layout have been applied. Previous studies have emphasized the potential usage of nanofluids instead of water as a solution to improve heat-transfer efficiency for smart thermal grids [8-10]. Moreover, the implementation of intelligent metering and information and communications technology (ICT) may allow for counteracting and quick elimination of failures in DH networks [11]. However, this approach remains only briefly addressed in the literature. This review paper intends to present how the ideas of smart asset management may successfully be applied to district heating systems with a focus on selected Baltic Sea countries. Due to moderate and harsh winter conditions in several Baltic Sea countries, the selection of the proposed location as a field for in-depth analysis of heat distribution systems seem to serve as an excellent reference example for other locations in the world that have similar climate conditions.

In this paper, the search for reference information and data in further sections was done using the following databases: ScienceDirect, Web of Science, and Google Scholar. The following keywords were used during the search: District Heating System, District Heating Network, District Heating Generation, Smart Grid, Smart Asset Management, Smart Maintenance, Intelligent System, etc. To the best knowledge of the authors, this is the first review paper on the application of the smart asset management concept in district heating systems.

\section{District Heating Systems}

\subsection{Energy Sources}

The European Union's goal to address climate change and the global demand for energy is the provision of climate-neutral energy systems by 2050, which requires shifting from the utilization of fossil fuels towards the application of renewable energy sources [12]. District heating systems are classified as one of the most important sectors to be optimized with respect to profitability and environmental impact, meaning implementation of sustainable and decarbonized energy [13]. Even though heat generation exceeds $40 \%$ of the total energy use in Europe, only a small percentage, approximately $11-12 \%$, of heat demand was delivered by district heating systems (DHS) in 2017 [14]. Nowadays, district heating systems are mainly supported by combined heat and power plants (CHP), commonly 
based on the combustion of fossil fuels, for instance, coal, natural gas, or petroleum [15]. Nevertheless, DHS presents flexibility in terms of feedstock; thus, incineration of municipal solid waste (MSW) or integration of waste heat from industrial sites is also possible [16,17]. A new direction is the implementation and extension of using renewable energy sources, including solar thermal energy and geothermal energy, as well as biomass fuels [18-20].

One of the ideas is "waste to energy" technology, which implies the use of waste as a feedstock to produce energy in the form of power and heat. This is achieved by means of pyrolysis, gasification, and incineration [21]. Thermal treatment of municipal solid waste is not only a way to minimize the number and area of landfills but also to develop technology to recover energy accumulated therein into valuable heat for $\mathrm{DH}$ applications. Another advantage of the "waste to energy" approach is the reduction of both fossil fuel consumption and greenhouse gas (GHG) emissions [22]. Tsai [23] estimated that MSW containing combustible material such as paper, textiles, woods, food waste, and plastic with $50 \%$ moisture possess a higher heating value (HHV) equal to about $2500 \mathrm{kcal} / \mathrm{kg}$. A higher value was obtained by Rudra et al. [24], and the MSW energy content was about $22 \mathrm{MJ} / \mathrm{kg}$, depending on the moisture content and amount of incombustible materials. Thus, a proper sorting process is needed to provide sufficiently high efficiency of the process. Sun et al. [17] evaluated the efficiency of solid waste energy recovery and $\mathrm{CO}_{2}$ emission reduction. Researchers stated that the efficiency of steam production from waste incineration is better than power generation, with fossil fuel reduction being two-times greater for steam than for power generation. They predicted that energy recovery efficiency might be about $66 \%$ with a corresponding reduction of $\mathrm{CO}_{2}$ emissions of $6.58 \times 10$ tons. However, they pointed out that the key aspect is the localization of incinerators in the vicinity of $\mathrm{DH}$ grids.

Developing biomass district heating (BioDH) systems is a potential method to take advantage of agriculture and forestry residues or energy crops as an alternative to fossil fuels [25]. Due to the fact that biomass has lower energy density compared to fossil fuels, it is not economically feasible to transport the biomass over $80 \mathrm{~km} \mathrm{[26].} \mathrm{Therefore,} \mathrm{this}$ technology is especially encouraging as a local source for small towns. Lower mass density requires higher storage volumes [27]. Additionally, seasonal availability and uncertain quantity are a barrier to expanding its usage. However, the obvious benefit is the reduction of carbon emissions. The biomass implemented in DH systems consists mainly of wood chips, sawdust, wood pellets, briquettes, and bio-oil [28,29]. Biomass may be converted into energy via thermochemical or biochemical processes [30]. Thermochemical processes generate heat, electricity, or biofuels, while biochemical operations provide liquid and gaseous fuels [31-33]. An important parameter determining the possible application is the biomass quality, i.e., moisture content, heating value, and bulk density, which all affect the energy generation efficiency. Generally, as in the case of MSW, biomass with lower moisture content is desirable. According to Quirion-Blais et al. [28], the average heating value of wood residues received by the plant is $19.3 \mathrm{GJ} / \mathrm{kg}$, which is significantly higher than for municipal solid waste. Shahbaz et al. [34] concluded that synthetic natural gas (SNG) from 100 MW biomass gasification incorporated into a CHP plant provides about 27.35 MW for DH and 3.4 MW for power production.

The integration of industrial waste heat in DHS is a different approach to decrease the consumption of fossil fuels and GHG emissions. Because a significant amount of low-grade waste heat from manufacturers (mainly in the temperature range between 30 and $120^{\circ} \mathrm{C}$ [35]) is dissipated into the atmosphere during the production processes, huge quantities of potential energy are lost $[22,36,37]$. Thus, it is deeply advisable to recover, collect, and reuse such industrial waste heat in DH systems. In 28 countries of the European Union, the entire waste heat potential in industry is predicted to be about $300 \mathrm{TWh} /$ year, while one-third of the waste heat has a temperature level below $200{ }^{\circ} \mathrm{C}$ [36]. Waste heat at a high-temperature level is reused directly for production processes. Meanwhile, heat at an intermediate temperature level may be recovered by heat exchangers for district heating [35]. However, using this source of energy is principally limited to small districts 
and the energy is regularly reused by the factory itself or in buildings in the vicinity, without long-distance transfer. The size of the heating area is often insufficient and therefore the heat demand does not rise enough to match the waste heat available from the factory, resulting in an insufficient recovery ratio. Moreover, the waste heat recovery process is straightforward only if a single waste heat source is applied [38]. Fitó et al. [39] evaluated valorization of waste heat from the French National Laboratory of Intense Magnetic Fields. The researchers suggested that the demand-oriented design led to recovering waste heat at $35^{\circ} \mathrm{C}$ with a heat pump and storage of $40-\mathrm{MWh}$, increasing the coverage of residential needs by up to $49 \%$. Meanwhile, the source-oriented design with recovering waste heat at $85^{\circ} \mathrm{C}$ without a heat pump and with storage of $40-\mathrm{MWh}$ reached the highest recovery of waste heat of approximately $55 \%$. Nowadays, utilizing geothermal energy (GE) as a renewable source for $\mathrm{DH}$ systems is being extensively investigated. GE is the cleanest form of energy obtained from the radioactive decay of minerals such as $\mathrm{U}$, Th, and $\mathrm{K}$, and has vast worldwide resources [40]. Geothermal resources provide base-load energy owing to their non-intermittent character, which is not affected by weather conditions [41]. In Europe, GE is directly utilized in 32 countries, accounting for more than $40 \%$ of the world's direct utilization [42]. Geothermal energy sources already produce more than the equivalent of four million tons of oil annually for DHS in the EU, equivalent to more than 15 GWth installed capacity, with geothermal heat pump systems contributing the biggest share [43]. Geothermal sources may be classified into three groups, according to the available temperature. These include shallow GE with low temperature, hydro-geothermal energy with low-medium temperature, and hot dry rock with higher temperature and greater energy density [41]. CHP systems might directly apply low-medium and hightemperature sources, while using low-temperature GE accumulated in-ground soil requires geothermal heat pump systems.

Solar thermal energy might be a notable source of renewable energy for DH systems. Solar district heating (SDH) refers to large-scale district heating systems equipped with solar collectors as part of the integrated heat supply. According to the analysis by Weiss et al. [44], up to 2016 the World installed area of solar collectors included in the DH system was about 1.65 million $\mathrm{m}^{2}$, which represents only about $0.3 \%$ of all global solar collectors. Moreover, annual solar thermal energy yield in 2017 amounted to $388 \mathrm{TWh}$, which led to saving about 41.7 million tons of oil and 134.7 million tons of $\mathrm{CO}_{2}$ [45]. The main advantages of SDH include the reduction of operating costs and greenhouse gas emissions, and is a potentially pollution-free method with $100 \%$ renewable source. Huang et al. [46] proposed several rules that guarantee the effective performance of SDH. The most significant included installation of SDH plants in a smaller town with the distance from the collector field to the DH network being within $200 \mathrm{~m}$. Furthermore, the lower temperature of about $70-80{ }^{\circ} \mathrm{C}$ for $\mathrm{DH}$ supply and $35-40^{\circ} \mathrm{C}$ for return are important parameters that are needed in order to reach a high efficiency of solar collector integration with the $\mathrm{DH}$ network. The authors proposed the connection of SDH with seasonal energy storage as an optimal solution.

\subsection{District Heating Generations}

District heating systems constantly evolves, and the driving force strives for lower heat and maintenance costs and higher efficiency with the sustainable development of non-fossil and renewable-based energy systems, simultaneously reducing greenhouse gas emissions. Figure 1 shows the timeline of development of DH generations with characteristic parameters. 


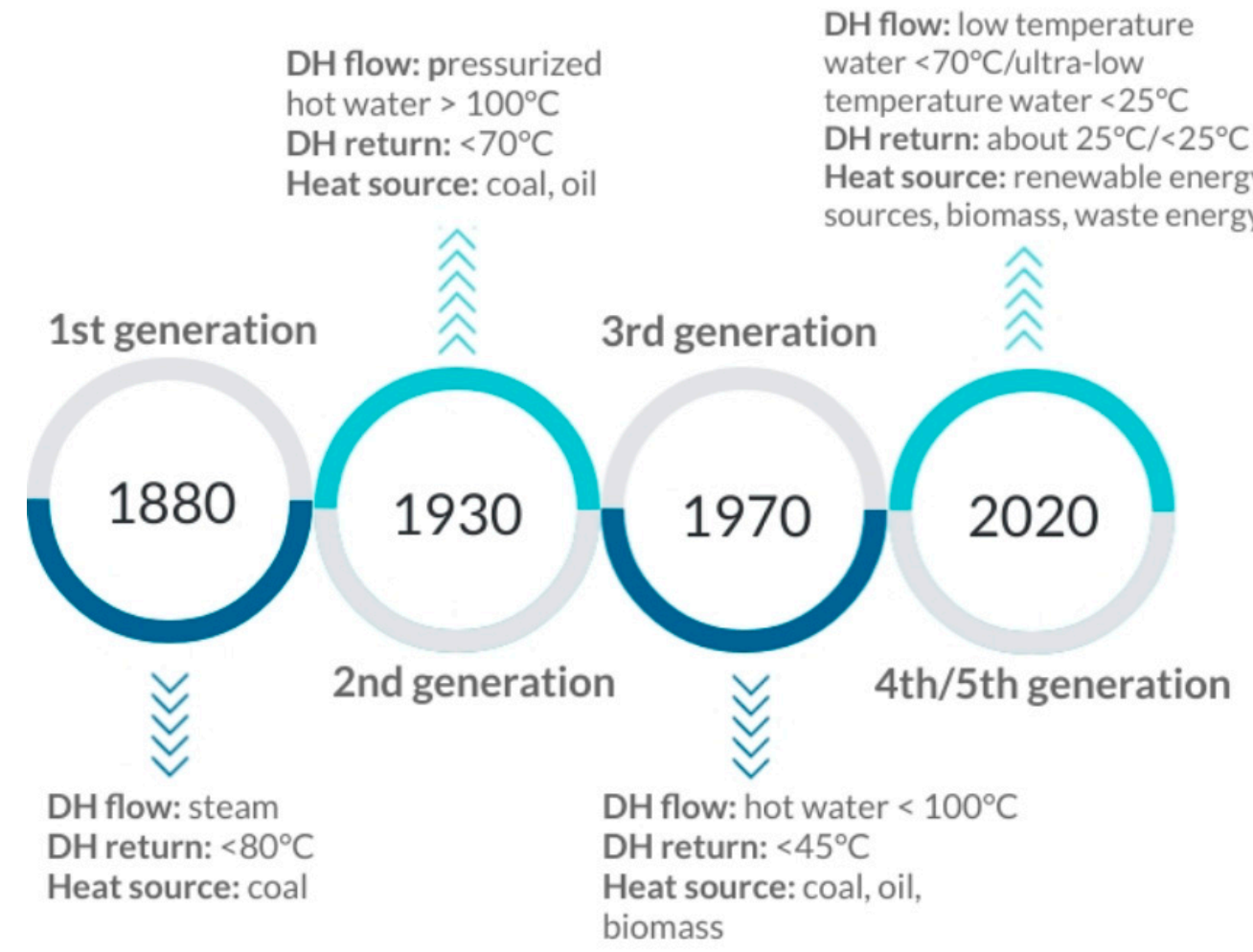

Figure 1. Timeline of district heating $(\mathrm{DH})$ generations.

First generation DH systems were developed in the USA in the 1880s and were exploited until the 1930s. These DHS involved the combustion of coal for steam generation, which was the first heat transfer medium carried by the network to the consumer. Steambased systems required a complex condensate structure; thus, servicing and maintenance costs were high. Moreover, high operating temperatures caused significant heat losses, especially with weak-insulated pipe systems, and therefore long-distance transport was not possible [47,48].

Second generation DH were introduced in the 1930s and was developed until the 1970s. These systems applied pressurized hot water with a temperature above $100{ }^{\circ} \mathrm{C}$, instead of steam as a heat carrier. With this, heat transfer became safer and, together with better-insulated pipelines, bigger DH networks could develop. This system relied on a two-pipe closed-loop system, where the returning condensate could be reutilized or applied for lower grade heat demand. The significant aspect of the 2nd DH generation is the development of the combined heat and power plant (CHP), both for heat and electricity production, which guarantees substantial savings in energy loss and exploitation costs $[47,48]$.

Developing the third generation DH systems started in the 1970s and nowadays is the most commonly used technology. This mode uses high-pressure water but with lower temperature than in the 2 nd generation $\mathrm{DH}$, i.e., below $100{ }^{\circ} \mathrm{C}$. A standard $3 \mathrm{rd}$ generation DH network consists of underground pre-fabricated pipes, thinner than in the 2nd generation, with thermal insulation. Moreover, shell and tube heat exchangers were replaced by plate heat exchangers. Additionally, renewable energy sources started to be exploited for heat generation, including biomass [47,48]. These notable improvements led to boosting efficiency and lowering the costs of heat.

According to literature data, the fourth generation $\mathrm{DH}(4 \mathrm{GDH})$ is being introduced in 2020 and it is predicted to dominate up to the year 2050. Lund et al. [47] formulated five major requirements for $4 \mathrm{GDH}$ systems. These are the ability to provide heat with low grid losses and the potential to recycle heat from low-temperature sources and incorporate renewable energy sources. Moreover, other important aspects are the integration of district 
heating technology to smart energy systems and the provision of suitable planning, cost, and management functions associated with its transformation into a future sustainable energy system. The 4 th generation DH concept provides the development of CHP systems with the utilization of renewable energy sources such as biomass, solar thermal energy, geothermal sources, and more [49,50]. Fourth-generation district heating is able to provide low-temperature systems with supply temperatures below $50-60^{\circ} \mathrm{C}$ along with significantly smaller pipe dimensions and improved insulation. Thus, the heat losses of the network may be reduced and the heat transmission capacity of the network may be increased [51]. Lowering the supply temperature is possible due to improved heat transfer in heat exchangers. Additionally, thermal energy storage is said to play an important role in $4 \mathrm{GDH}$; therefore, the shift in time between thermal energy production and its utilization is not problematic [52]. Furthermore, the crucial innovation deals with intelligent control and metering of DH network performance as well as heat demand forecasting [53].

The idea of evolving the fifth generation district heating and cooling (5GDHC) networks is relatively new and has not been widely described in the literature. The proposed innovative method assumes a bidirectional low-temperature network supplying water with a temperature lower than $25^{\circ} \mathrm{C}$, close to ground temperature, in a so-called "ambient loop", in order to reduce heat losses to a minimum [54]. In this system, thermal networks include warm and cold pipes, whereby the temperature of water in a warm pipe is about $5-10{ }^{\circ} \mathrm{C}$ higher with respect to a cold pipe. Decentralized heat pumps using water from a warm pipe as a heat source enable sufficient water temperature for space heating purposes or domestic hot water. Then, cooled water from the evaporator is evacuated to a cold pipe. Conversely, chillers utilize water from the cold pipe and remove heated water to a warm pipe [55]. Furthermore, the system is facilitated with seasonal heat storage. Buffa et al. [14] suggested that negligible thermal losses, recovering low-temperature excess heat, and usage of renewable energy sources are one of the most essential characteristics of the 5 GDHC system. Moreover, these 5th generation systems involve integrated smart network control using artificial intelligence [54]. This might be helpful to promote optimal control and maximize the benefits of exchanging heat or cold between connected buildings instead of direct transport of heat or cold from the supplier. Each consumer may transfer the excess of heat or cold to the network, and hence act as a producer [56]. In this way, the heat losses are limited, resulting in economic and ecological profits. Artificial intelligence solutions may be needed for the optimization of pipelines network configuration, connection of new customers, prediction of heat demand, or matching of the heat sources. Fifth generation DH has already been introduced in Plymount (UK) and Heerlen (Netherlands). Additionally, pilot projects are being tested in Germany. The Mijnwater DHC system in Heerlen (Netherlands) is one of the most advanced 5th generation DHC systems from a technological point of view. This system includes an urban smart DHC grid, incorporating several decentralized heat sources, a data processing center, and residual heat from supermarket refrigerators and from small scale industrial processes, along with the warm return flow from space cooling in the connected buildings. Nowadays, Mijnwater supports over $200,000 \mathrm{~m}^{2}$ of building floor area [57].

\section{Exploitation Issues of DH Networks}

\subsection{Low Efficiency of Heat Supply Systems}

The principal exploitation issue associated with district heating is the low efficiency of the system. One of the circumstances determining this low-efficiency is very often the relatively high difference between the heat demand and the heat load of buildings connected to the DH network, which may arise from variable external temperatures during the heating season or differences in heat demand and accumulation between the buildings [2,58-60]. In this case, the main solution is the forecasting of the heat demand based on weather conditions [61] or application of an individual metering system. A different obstacle with $\mathrm{DH}$ efficiency refers to the low number of thermal storage systems [60]. The increase of the heat storage system enables storage of the extra energy produced by the $\mathrm{DH}$ plant during 
the low heat requirement period. Another limiting factor for the efficiency of DH systems is heat loss. Reduction of the temperature supply, application of pre-insulated pipes, the optimal length and diameter of the pipes (preventing over-dimensioning of pipes), and short heat transmission lines from heat plants to consumers have been proven to limit the level of heat losses form the DH network [62-64].

\subsection{Heat Supply Problems}

The heat supply problems are related to an excessively high flow of heat transfer media in the DH network relative to the pipe diameter. This results in problems with maintaining the sufficient differential pressure in the system $[65,66]$. Generally, this phenomenon occurs with too small diameter pipelines when more consumers are connected to the DH network. Elimination of this problem may result in lowering the supply temperature or reduction of the pumping power. Earlier, the before-mentioned difficulties were solved by an increase in temperature supply or an increase in the pipe diameter. However, nowadays, different solutions are taken into accounts, including the application of pumps, a local heat supply, or demand-side management.

\subsection{Failures in DH Networks and Customers Installations}

Another problem regarding the DH system are failures in the DH networks or customer installations, usually arising from outdated DH networks or lack of DH network inspections, as well as poor system monitoring [59]. Leakages and blockages are significant problems related to the $\mathrm{DH}$ pipeline system [51,67]. The main reasons for leakage are corrosion, equipment aging, the impact of ground loads, or mechanical factors [68]. Leakages cause loss of medium or energy, which affects the efficiency of heat transfer and related economic aspects. Furthermore, in situations using steam or hot water as a heat transfer medium, leakages are posing a risk to consumer safety and have a negative environmental impact. Blockage of flow is caused, for example, by local chemical or physical deposition or water freezing in cold climates. The blocking of pipelines causes energy losses and flow separation, which decreases the efficiency of the heat supply [69]. Because it is not possible to eliminate them completely, systems for early detection are needed to provide data about the location and size of the blockage.

Meanwhile, customer installation faults are described as the fault of the heat exchangers, control systems, actuators, control valves, or internal heating system of the customer. First of all, it is the fouling of the heat exchanger-deposits on heat transferring elements, that increase the resistance to heat transfer and flow in the heat exchanger. Moreover, the failures may be related to incorrect installation of heat exchangers, where the water flow pattern is co-current instead of counter-current. A common problem is related to leakages from heat exchangers. Defects may also concern temperature sensors. This may result in an excessive return temperature level or losses of heat transfer medium. Furthermore, problems with valves appear when these are oversized, thus affecting the flow when the valve position changes, making it difficult to set small flows through the valve [59].

\subsection{Environmental Issues}

Carbon dioxide released from the combustion of fossil fuels is a dominant reason for global warming. Combustion of coal emits more than $350 \mathrm{~kg} \mathrm{CO}_{2} / \mathrm{MWh}$ energy while natural gas emits more than $200 \mathrm{~kg} \mathrm{CO} / \mathrm{MWh}$. According to data from 2018, in the $\mathrm{EU}$, about $75 \%$ of heating and cooling is still produced from fossil fuels [70]. Therefore, following the European Union long-term objective of reducing greenhouse gas emissions by $80-95 \%$ by 2050 and the target of a $40 \%$ reduction by 2030 compared with the 1990 level [71], it is essential to implement renewable energy sources such as solar, wind, and geothermal energy or utilize waste heat with zero $\mathrm{CO}_{2}$ emissions. Moreover, increasing the efficiency of $\mathrm{DH}$ by thermal storage may help to limit $\mathrm{CO}_{2}$ emissions. 


\subsection{Occurrence of Legionella in LTDH Systems}

Low-temperature water supply, i.e., below $55^{\circ} \mathrm{C}$, constitutes a favorable environment for the growth of Legionella bacteria, which cause Legionnaire's disease [72]. The simplest solution for preventing Legionella growth is a high-temperature regime and hot water circulation in households. However, in low-temperature DH generation systems, this solution is not satisfactory. Hence, Yang et al. [73] proposed an alternative design using decentralized substation and micro heat pumps or other sterilization techniques such as ionization, UV light, chlorine addition, or the application of filters.

\section{Traditional Maintenance Approach Versus Smart Asset Management for District Heating Networks-If "Prevention is Better than Cure"?}

Significant heat losses due to higher heat load than heat demand, leakages in the case of system damage, and difficulties with pipeline inspections leading to problems with finding the location of faults-this is how old, traditional DH Systems without monitoring, controlling, or alarm equipment might be described. In this system, maintenance and repair are based on the reactive (corrective) approach, which means that actions are taken when failure occurs. The new approach is called a smart district heat network-i.e., systems with a proactive and condition-based strategy. Such systems are characterized by optimization of heat load and intelligent control of the network, including information and communication technologies; effective automatic control in real-time in the areas of heat generation, distribution, and consumption; interactions with customers; early detection of errors; and a series of measurements and modeling operations. These solutions provide safe, efficient, and cost-effective DH systems. The most commonly proposed ideas and innovations for Smart DHS are presented below.

\subsection{Smart District Heating (sDH) Bi-Directional System with Prosumers Idea and Thermal Energy Storage}

In smart DH, different parts of the system, i.e., thermal source, pipelines, substations, and consumers, are connected and integrated into a long-distance management and intelligent system. According to Gao et al. [2], sDH consists of a control center, a communication network, a geographic information system (GIS), supervisory control, and a data acquisition system.

The sDH development strategy involves design optimization of the distribution system, i.e., network layout, pipe size and insulation, or underground depth [74]. All the above-mentioned features directly affect the construction cost, performance, heat loss, and a resulting differential pressure of the pipeline. In a sustainable system, consumers should be close to the site of heat generation to reduce the length of the distribution line. The depth of the DH pipe should be about 0.6-1.2 $\mathrm{m}$ underground, where the soil temperature is relatively stable. Furthermore, the application of the so-called hybrid insulation of pipelines with polyurethane and vacuum insulation panels are said to decrease the heat loss by $15-20 \%$ in comparison to pipe insulated with pure polyurethane. A reliable design mode applies optimization algorithms to determine the most suitable pipe diameters, insulation layer, or layout [74].

Novel bi-directional substations using a single circuit for both district heating and cooling proposed by 5 th generation DH ideas are also part of the sDH strategy $[4,75]$. In the case of higher demand in the network for cooling than heating, the system circulates from a central plant in one direction. When more heat is required, the system circulates in the opposite direction.

Smart DH includes the approach of so-called prosumers-households that can be both consumers and producers of heat [5,76]. Prosumers possess heat sources (HS) and energy storage devices that allow them, based on the balance between their needs and capabilities, to regulate the amount of heat, depending on the energy received from the system $[77,78]$. These units, which collect heat or cold, are used to level off the constraints of short-term variation and to provide continuous energy supply. Thermal energy storage provides peak 
shaving and time-varying management, relieving renewable energy intermittence and lowering operating costs.

\subsection{Demand Site Management with Heat Demand/Load Forecasting}

Demand site management (DSM), so-called demand response, is one of the strategies used for the optimization of DH system operation. This technology is based on the forecast of the thermal request profile at the building level and the management of optimal schedules for heating systems or control strategies, thus reducing consumption and peak demand. Thermal request profiles illustrate how the heat is consumed by households, and they may be compared for a different location or time. DSM measures should be beneficial both for DH companies (heat consumption variations are balanced) and for consumers (lower energy costs) $[79,80]$.

Guelpa et al. [81] proposed a multi-level thermal request prediction for buildings in the DH network for the case study in Turin. The method consists of the following two steps. The first is a black-box model-a smart prediction of the thermal demand evolution of the buildings based on data available in the buildings connected to the DHS, i.e., inlet and outlet temperatures and mass flow rate on the primary side. The second step is a network physical model, combining the demand of the buildings with fluid flow and heat transfer in the DH network. The results showed that the applied prediction model for buildings and the $\mathrm{DH}$ network was able to determine the request profiles with an error below $10 \%$. Furthermore, the authors stated that the proposed model is appropriate for large DH networks due to its compactness-the low number of input data and simplicity of application and implementation together with low computational costs. Meanwhile, Idowu et al. [82] proposed machine learning for the prediction of heat demand in buildings connected to the DHS located in Skellefteå, Sweden. The heat load forecast models were generated using supervised machine learning techniques, in comparison to other methods, including support vector machine, regression tree, feed-forward neural network, and multiple linear regression. The proposed model takes into account parameters such as outdoor temperature, historical values of heat load, time factor variables, and physical parameters of DHS as its input. The obtained results revealed that the support vector machine was the most suitable machine learning method and has the least normalized root mean square error of 0.07 for the forecast horizon of $24 \mathrm{~h}$.

From the theoretical viewpoint, application of DSM for thermal peak shaving according to Guelpa et al. [83] might have many advantages. These including the possibility of exploiting DH system capabilities, increasing potential for the connection of other buildings to DH networks without modifying the pipeline by making the request as low as possible, or a more effective combination of thermal and electrical energy production. Kontu et al. [84] presented an example of a case study that compared households with implemented smart control actions and customers who did not apply any DSM solutions, in two Finnish cities-Espoo and Vantaa. The benefits of DSM were evaluated from the perspectives of a point customer and a DH company. The results confirmed that customers with implemented DSM solutions decreased heat consumption and thus lowered their energy costs. However, the benefits were not observed by the DH companies, and higher short-term variations in the heat load were observed.

\subsection{Multi-Heat Source (MHS) for DH with Integration of RES}

Traditional DH systems are usually based on one heat source that provides heat to a single district. Other principals are implemented for Smart DH with the employment of multi-heat a source strategy. The use of intelligent control systems led to the selection and matching of the most profitable heat sources. These MHS systems can efficiently promote the utilization of local renewable energy sources and waste heat. Generally, MHS consist of a CHP plant as a major heat source with maximum heat capacity and additional, supporting heat sources such as solar thermal energy, wind energy, or waste heat, which are regulated to meet the different heat demands of consumers. In such a way, the effectiveness 
of DH systems may be improved. This complex system is a flexible and reliable solution, with a limited number of possible failures. If any problem occurs with one heat source, the system should still be able to operate [2,85-87].

\subsection{DH Network and Household Integrated into Intelligent System}

Smart DH systems are based on sensors and devices such as IT hardware and software, smart grid integrated communications, and metering hardware and software [88]. Various devices measure diagnostic signals that carry information about the actual state of the equipment. The signal goes through the primary selection of diagnostic information and then is fully processed and analyzed by the control center. Intelligent control systems might supervise all elements integrated into heat production, distribution, and consumption. DH plants and households are connected to one smart network [2]. This smart supervision manages to diagnose the technical condition of plants, pipelines, and equipment, identify all possible defects, faults, or dangerous situations in a continuous manner with a rapid response of alarm signals. Moreover, the prediction and planning of heat loads with respect to weather conditions and historical data are also included [89-91].

Zhong et al. [92] described the smart saliency analysis method for DHS pipeline leakage detection, applying remotely multi-source data from sensed infrared imagery, visible imagery, and geographic information system (GIS). Pipeline leakages are salient in the infrared imagery as the leaked material creates a local high-temperature area. The false alarm rate might be limited by combining multisource data analysis. GIS data from pipelines led to the removal of the potential of false leakage locating outside the pipeline area.

Ahn and Cho [93] proposed an intelligent controller to improve thermal comfort and reduce the peak demand in a DH system. The model, based on artificial intelligence with temperature and thermal comfort detectors, was used to maintain the desired room temperature. Application of the model resulted in a decrease of peak demands in order to optimize the DH distribution capacity. Comparative analysis proved that the model maintained thermal comfort level and decreased peak demands by $30 \%$, compared to a conventional on/off controller.

Wang et al. [94] proposed a control model for the detailed estimation of heat loss for buried pipes and thermal deterioration of pipe insulations. The temperature, pressure, and flow rate meters are included to provide real-time data at the inlets and outlets of each heat source and substation. The complex heat loss profile along pipes might be defined by the presented model, and thus the accuracy of the location of damaged insulation might be enhanced. Moreover, the thermal deterioration of buried pipes may be evaluated conveniently; thus, aging or corrosion are more easily detected.

\subsection{Selected Examples of Smart Solutions for DH Systems}

Smart active box (SAB), proposed by the Arne Jensen AB company (Sweden), is an example of a smart solution for DH systems. It is a controller that enables leak detection by Delta- ${ }^{\circledR}$ measurement based on a unique acoustic module. The SAB unit is installed in a $\mathrm{DH}$ chamber. Measurement data are collected from the sensors according to the desired frequency, ranging from every six minutes to once a day. The sound and signal analysis provide information about temperature and humidity in the chamber, contact temperature on the supply and return line, the flood alarms, and recordable audio files [95]. Such an approach allows for monitoring of the DH network between the adjacent chambers.

STORM controller (Belgium) is a smart district heating and cooling network management system based on self-learning algorithms. This controller includes three main modules, i.e., an energy forecaster, the operational optimization planner, and the demandside management tracker, and uses three different control strategies: peak shaving, market interactions, and cell balancing [96].

FLEXYNETS (Germany) is a single system control with a centralized intelligent control platform. This platform includes a high-level controller that interacts with a strategic 
control platform, supporting the control decisions and strategies by weather forecast data in combination with simulation models of the entire system. Weather forecast data and simulation tools help to optimize the control strategies a day in advance [97].

Danfoss Link ${ }^{\mathrm{TM}}$ app (Denmark) enables the control of room temperature via an application on a smartphone connected to the central controller, room, and floor thermostats. The application enables intelligent adjustment of room temperatures to the schedule of the day with a lower temperature at night, including a weekly plan, holiday, or absent mode [98].

Vexve intelligent valve solution (Finland) operates underground without an external power supply and transmits the information to a cloud service. Through the application of an intelligent valve, the temperature, humidity, and network pressure variations are monitored continuously. Thus, leakage points linked to leak detection cables can be immediately localized [99].

\subsection{Estimated Revenues from Using SAM Methods in District Heating Networks}

It is generally assumed that there are three areas in which application of smart asset management may be beneficial to both district heating companies and consumers. These are social, technical, and economical areas and include increased durability and usage safety of the networks, reduction of number and frequency of failures, and economical benefits. The installation of SAM solutions in DH networks is aimed at prolonging the exploitational time of the network and can be used to plan retrofitting and maintenance operations. This, in turn, results in a much lower number of failures and shortens the time when consumers are deprived of a heat supply. The following analysis on the possible revenues may be proposed. According to operational data from the Lithuanian District Heating Association, the annual maintenance cost per kilometer of network is about 950-1150 EUR. Without proper preventive monitoring methods, failures in the network are hardly foreseen. Assuming the failure of a typical $100 \mathrm{~mm}$ tube, its repair may cost up to several thousand EUR. This is because the failure must be initially localized, then the pipe must be excavated, drained, repaired, and buried, and the original state of the landscape must be restored. It must be noted that this analysis excludes the costs of depreciation as well as the potential costs related to disappointed heat consumers.

The average maintenance costs related to the pipe replacement are in the range of 250-2350 EUR per $1 \mathrm{~km}$, for a diameter of roughly 70-600 mm, respectively. In Lithuania, for example, the normative depreciation period of a DH section is 35 years. The savings from applying SAM solutions may be calculated on the basis of prolongation of the operational time. Thus, if the operational time is prolonged by 1 year, the resulting savings are about $1 / 35$ of the initial cost. Swedish district heating company, Örresundskraft, reports that installing the moisture bands on the pipes in the Helsingborg region results in about 250,000 EUR saving per year [100]. However, the precise evaluation of the possible prolongation period of network exploitation and savings is very hard and requires new experimental data, coming from, e.g., already installed SAM solutions. Databases on the development of damages in DH networks (regarding both different types of failures as well as damage to pipe materials) as a function of their lifetime are missing. Currently, the German Energy Efficiency Association for heating, cooling, and CHP (AGFW) is building up such a database for Germany, Austria, and Switzerland (the so called DACH region) [101].

\section{Overview of District Heating Systems in Selected Baltic Sea Countries}

This section provides an overall overview of the current status of DH systems and strategies for the future development in seven Baltic Sea Countries, i.e., Poland, Sweden, Finland, Latvia, Lithuania, Germany, and Denmark. Table 1 presents a brief summary of the current status of DH systems in the above listed countries, while Table 2 presents selected projects in the field of district heating systems involving partners from the Baltic Sea Region, both completed and still on-going since 2016. 
Table 1. Current status of district heating systems in selected Baltic Sea countries-a summary.

\begin{tabular}{|c|c|c|c|c|c|c|}
\hline Country & $\begin{array}{c}\text { Share of District } \\
\text { Heating in } \\
\text { Residential Sector, \% }\end{array}$ & $\begin{array}{l}\text { Main Heat } \\
\text { Source/Heat } \\
\text { Production }\end{array}$ & $\begin{array}{l}\text { Share of } \\
\text { RES, \% }\end{array}$ & Current Status & $\begin{array}{c}\text { Typical } \\
\text { Supply/Return } \\
\text { Temepratures, }{ }^{\circ} \mathrm{C}\end{array}$ & Goals \\
\hline Poland & 42 & $\begin{array}{l}\text { Hard coal and } \\
\text { coal product } \\
\text { cogeneration } \\
\text { plants }\end{array}$ & 7.4 & $\begin{array}{l}\text { Transformation } \\
\text { into 3rd } \\
\text { generation } \\
\text { system }\end{array}$ & $135 / 70$ & $\begin{array}{l}\text { By 2030: reduction of } \\
\mathrm{CO}_{2} \text { emissions by } 42 \% \text {, } \\
\text { increase of share of RES } \\
\text { up to } 50 \% \text {; by } 2050 \text { : } \\
100 \% \text { reduction of } \mathrm{CO}_{2} \\
\text { emissions (with respect } \\
\text { to reference year } 1990 \text { ) }\end{array}$ \\
\hline Denmark & 65 & Biomass and solar & 58.9 & $\begin{array}{l}\text { Transformation } \\
\text { from 3rd to } 4 \text { th } \\
\text { generation } \\
\text { system }\end{array}$ & $80 / 40$ & $\begin{array}{l}\text { By 2050: zero } \mathrm{CO}_{2} \\
\text { emissions and fossil } \\
\text { independence }\end{array}$ \\
\hline Sweden & 50.4 & $\begin{array}{c}\text { Biomass and } \\
\text { waste heat }\end{array}$ & $>65$ & $\begin{array}{l}\text { 3rd generation } \\
\text { system }\end{array}$ & $86 / 47$ & $\begin{array}{c}\text { By 2045: } \\
\mathrm{CO}_{2} \text {-neutrality }\end{array}$ \\
\hline Finland & 38 & $\begin{array}{c}\text { Coal and } \\
\text { wood-derived } \\
\text { fuels }\end{array}$ & 55 & $\begin{array}{l}\text { 2nd and 3rd } \\
\text { generation } \\
\text { systems }\end{array}$ & $65-115 / 40-60$ & $\begin{array}{l}\text { Development of nuclear } \\
\text { power and solar heating }\end{array}$ \\
\hline Lithuania & $>65$ & $\begin{array}{l}\text { Biomass and } \\
\text { municipal waste }\end{array}$ & $>65$ & $\begin{array}{l}\text { 3rd and 4th } \\
\text { generation } \\
\text { systems }\end{array}$ & $\sim 85 / 45$ & $\begin{array}{l}\text { By 2050: zero } \mathrm{CO}_{2} \\
\text { emissions, } 80 \% \text { of RES } \\
\text { share }\end{array}$ \\
\hline Germany & 13.8 & $\begin{array}{l}\text { Combined heat } \\
\text { and power plants }\end{array}$ & 12 & $\begin{array}{l}\text { 3rd and 4th } \\
\text { generation } \\
\text { systems }\end{array}$ & $\sim 85 / 45$ & $\begin{array}{l}\text { By 2050: } 100 \% \text { of RES } \\
\text { share and } 80 \% \\
\text { reduction of } \mathrm{CO}_{2} \\
\text { emissions (with respect } \\
\text { to reference year 1990) }\end{array}$ \\
\hline Latvia & 30 & $\begin{array}{l}\text { Central heat } \\
\text { pumps, natural } \\
\text { gas and biomass }\end{array}$ & 47 & $\begin{array}{l}\text { 2nd and 3rd } \\
\text { generation } \\
\text { sysmtems }\end{array}$ & $\sim 85-130 / 45-70$ & $\begin{array}{c}\text { By } 2050: \mathrm{CO}_{2} \text { reduction } \\
\text { by } 80-95 \% \text { (with respect } \\
\text { to reference year 1990) } \\
\text { fossil independence }\end{array}$ \\
\hline
\end{tabular}

RES—renewable energy sources.

Table 2. Summary of district heating (DH) projects ongoing from 2016 with participating countries from the Baltic Sea Region.

\begin{tabular}{|c|c|c|c|c|}
\hline Project & $\begin{array}{l}\text { Baltic Sea Region } \\
\text { Project Partners }\end{array}$ & $\begin{array}{l}\text { Years of } \\
\text { the Project }\end{array}$ & Main Goals & Reference \\
\hline $\begin{array}{c}\text { LowTEMP (Low Temperature } \\
\text { District Heating for the Baltic } \\
\text { Sea Region) }\end{array}$ & $\begin{array}{c}\text { Denmark, Finland, } \\
\text { Germany, Latvia, } \\
\text { Lithuania, Poland, } \\
\text { Sweden }\end{array}$ & $2017-2021$ & $\begin{array}{l}\text { (1) Combining low-temperature } \mathrm{DH} \\
\text { solutions with energy supply systems } \\
\text { (2) Promoting energy efficiency and the } \\
\text { application of renewable energy sources } \\
\text { (RES) with the reduction of } \mathrm{CO}_{2} \text { emission }\end{array}$ & [163] \\
\hline $\begin{array}{c}\text { BSAM (Baltic Smart Asset } \\
\text { Management) }\end{array}$ & $\begin{array}{l}\text { Lithuania, Poland, } \\
\text { Sweden }\end{array}$ & 2019-2022 & $\begin{array}{l}\text { (1) Distinguishing limitations and profits } \\
\text { for the implementation of smart asset } \\
\text { management (SAM) and digitalization of } \\
\text { DH distribution networks } \\
\text { (2) Developing nationally adapted methods } \\
\text { for condition monitoring of district heating } \\
\text { systems (DHS). }\end{array}$ & [164] \\
\hline HRE4 (Heat Roadmap Europe 4) & $\begin{array}{l}\text { Finland, Germany, } \\
\text { Poland, Sweden }\end{array}$ & 2016-2019 & $\begin{array}{l}\text { (1)Improving at least } 15 \text { new policies at the } \\
\text { local, national, or EU level for } \\
\text { decarbonization of district heating and } \\
\text { cooling (DHC) systems } \\
\text { (2) The setting of how to save } \\
\text { approximately 3,000,000 GWh/year of } \\
\text { fossil fuels in Europe. }\end{array}$ & [165] \\
\hline
\end{tabular}


Table 2. Cont.

\begin{tabular}{|c|c|c|c|c|}
\hline Project & $\begin{array}{l}\text { Baltic Sea Region } \\
\text { Project Partners }\end{array}$ & $\begin{array}{l}\text { Years of } \\
\text { the Project }\end{array}$ & Main Goals & Reference \\
\hline $\begin{array}{l}\text { InDeal (Innovative Technology } \\
\text { for District Heating and Cooling) }\end{array}$ & Finland, Poland & 2017-2019 & $\begin{array}{l}\text { (1) Offering a novel platform that will } \\
\text { manage a fair distribution of heating and } \\
\text { cooling in the DHC network by real-time } \\
\text { energy demand data collected using } \\
\text { artificial intelligent meters and classifying } \\
\text { the network's building demand. } \\
\text { (2) Turning the current DHC systems into } \\
\text { innovative high-level computerized DHC } \\
\text { systems. }\end{array}$ & [166] \\
\hline $\begin{array}{l}\text { RELaTED (REnewable Low } \\
\text { TEmperature District) }\end{array}$ & $\begin{array}{l}\text { Denmark, Poland, } \\
\text { Sweden }\end{array}$ & 2017-2021 & $\begin{array}{l}\text { (1) Providing a novel idea of decentralized } \\
\text { ultra low-temperature district heating } \\
\text { (LTDH), which enables the adding of } \\
\text { low-grade heat reservoirs } \\
\text { (2) Following the approach of the smart } \\
\text { grids, where heat production is } \\
\text { decentralized, and consumers become } \\
\text { prosumers. }\end{array}$ & [167] \\
\hline
\end{tabular}

THERMOS (Thermal Energy

Resource Modelling and

Optimisation System)

Denmark, Germany,

Latvia, Poland

2016-2020

2017-2021

TEMPO (TEMPerature

Temperature District Heating across Europe)
(1) Developing the methods, data, and tools to facilitate public authorities and other stakeholders to undertake a more sophisticated thermal energy system planning to incorporate real-world cost, benefit, and performance data

(1) Creating low temperature (LT) networks for raised network efficiency with the integration of renewable and residual heat sources.

(2) Developing innovative business models to promote LTDH network competitiveness.
W.E. District (Smart and local reneWable Energy DISTRICT heating and cooling solutions for sustainable living)
Denmark, Germany, Poland, Sweden

2019-2023

Demonstrating $\mathrm{DHC}$ as a joined solution that employs the combination of RES, thermal storage, and waste heat recovery to provide $100 \%$ of the heating and cooling requirement

(2) Incorporating integrated control technologies and decision making to DHC systems.

(1) Demonstrating high-level systems allowing the recovery and reuse of excess heat available at the municipal level.

ReuseHeat (Recovery of Urban Denmark, Germany, Excess Heat) Sweden

heating of Energy Efficien

Buildings with new Low

Temperature District Heating Solutions)

Keep Warm (Improving the performance of district heating systems in Central and East Europe)
Germany, Latvia

2018-2020
(2) Development, monitoring, and evaluation of four large scale cases showing the technical utility and financial profitability of waste heat recovery.
(1) Supporting municipalities in planning and expanding new, effective district DHC systems, extend and renovate existing units to higher standards.

(2) Designing LTDH systems with non-conventional pipe materials and controls inside buildings that link LTDH with the integration of locally generated renewable energy for low $\mathrm{DH}$ temperatures $\left(40-65^{\circ} \mathrm{C}\right)$.

(1) The growing energy effectiveness of $\mathrm{DH}$ systems by an acceleration of cost-effective investments in the modernization of DHS.

(2) Reducing greenhouse gas (GHG) emissions by promoting a switch from fossil fuel to renewable sources. 


\subsection{Poland}

Poland is the second, after Germany, greatest district heat producer in the European Union [102]. In 2017, the DH system satisfied $42 \%$ of the heat demand in the residential sector [103]. Polish DH networks provide heat for space heating for at least six months per year, depending on weather conditions. Nowadays, the highest share in DH is covered by hard coal and coal product cogeneration plants [103]. In 2015, the share of RES in district heating systems reached only about 7.4\% [104]. Many Polish citizens still use individual coal-fired boilers and stoves. However, The Clean Air Program, implemented by the Polish Government, assumed thermal modernization of Polish households with the simultaneous replacement of heat sources during the period 2018-2029 to enhance energy efficiency and diminish the emission of dust and other pollutants related to the problem of smog [105].

Nowadays, the major challenge for Polish DH is a step by step transformation into modern 3rd generation systems, with temperature supply below $100{ }^{\circ} \mathrm{C}$. The typical DH network supply temperature is $135^{\circ} \mathrm{C}$, while the return is $70^{\circ} \mathrm{C}$ for a large district heating system [106]. Cenian et al. [107] described the case study in a Polish town, Łomża, where DH system thermal modernization was introduced. The first stage of modernization led to decreasing the $\mathrm{DH}$ supply temperature from $121^{\circ} \mathrm{C}$ to $109.8^{\circ} \mathrm{C}$, with a reduction of about $14 \%$ of heat losses compared to the previous heating system and improvement in the hydraulic stability of the DH system. The oversized radiators, heat exchangers, and grids after thermal modernization of buildings are advantageous. An important element in Polish DH systems is thermal energy storage (TES) tanks that support ten Polish CHP plants, which provide heat source load-leveling for variable heat demand periods [108].

One of the directions of DH development in Poland is the use of geothermal energy as a heat source. Poland is one of the richest countries in Europe in terms of low-temperature geothermal resources. In Poland, four geothermal areas are distinguished, i.e., Polish Lowlands, Carpathian Province, Carpathian Foredeep, and Sudety Region $[109,110]$. The most valuable, from a heating point of view, are the areas of Carpathian Province as well as the Lower Cretaceous and Lower Jurassic reservoirs in the Polish Lowlands. The total installed capacity from six geothermal DH plants is $76.2 \mathrm{MWth}$ [110]. The outflow water temperatures vary from 20 to $97^{\circ} \mathrm{C}$, while water reserves amount from several L/s to $150 \mathrm{~L} / \mathrm{s}$, and heat flux values range from 20 to $90 \mathrm{~mW} / \mathrm{m}^{2}$ [109]. The implementation of geothermal heat sources has played an important role in the improvement of air quality in Poland. Moreover, geothermal DH plants could operate at lower temperatures, offering a higher efficiency of heat transfer.

The major Polish DH goals assumed two time limits, the first by the year 2030, with a reduction of $\mathrm{CO}_{2}$ emissions by $42 \%$ (compared to levels from 2016) and a share of $40 \%$ RES. The second limit is set at the year 2050, with the reduction of $\mathrm{CO}_{2}$ emissions by $100 \%$ (compared to levels from 2016) and utilization of $100 \%$ renewable energy [111].

\subsection{Denmark}

Denmark is one of the most advanced Baltic Sea Region countries in terms of DH systems. In 2017, about $65 \%$ of its citizens' heat demand was satisfied by DH systems. Currently, various Danish DH networks are going through the transformation from 3rd generation $\left(80 / 40{ }^{\circ} \mathrm{C}\right)$ to 4 th generation $\left(50-55^{\circ} \mathrm{C} / 25^{\circ} \mathrm{C}\right)$ networks [112].

The share of renewable energy sources for $\mathrm{DH}$ in 2017 was equal to $58.9 \%$, principally in the form of biomass [113]. However, Denmark is also a leader in both total installed capacity and number of large-scale solar DH plants. Furthermore, it is the first and only country with commercial market-driven solar DH plants. Until 2017, 110 solar heating plants, with more than 1.3 million $\mathrm{m}^{2}$ of collector area, had been operating in Denmark, which represents more than $70 \%$ of the total worldwide large scale solar DH plants. Solar $\mathrm{DH}$ production is expected to achieve $6000 \mathrm{TJ}$ in 2025 [114]. Moreover, an important part of the Danish solar DH systems is long term large heat storage, consisting of water pit storage, constructed in Marstal, Dronninglund, Vojens, and Gram, and boreholes in Brædstrup. The share of solar heating in a district heating system without heat storage is about $5-8 \%$ 
of the annual heat demand, while an application of diurnal heat storage reaches $20-25 \%$. Application of solar energy is also an economically efficient solution, because the cost of solar heat is in the range of 20-40 EU/MWh, while the heating price of natural gas boilers is higher than 60EU/MWh [114].

According to Buhler et al. [115], excess heat from industry might be applied as a resource for the Danish DH systems. The results for the case study for Denmark revealed that about 1.36 TWh of DH demand could be covered annually with industrial excess heat from thermal processes, which is equal to about $5.1 \%$ of the current usage. Additionally, more than half of the heat might be used directly, without the application of heat pumps.

Another option used in Denmark is the application of large scale heat pumps in DH systems. This solution may provide stable and efficient heat supply, especially when wind or solar electricity production is high, and might be converted into heat, and thus replace the heat produced by fuel boilers. According to Lund et al. [116], Denmark is well able to introduce heat pumps, with potential heat sources located close to all DH areas and, moreover, seawater will play a significant role as a heat source for Denmark in the future.

A smart approach in DH management in Denmark is presented by Foteinaki et al. [117], who described the cooperation between three DH companies in the Copenhagen metropolitan area, coordinated by Varmelast Company. The main task of Varmelast Company is related to the preparation of the day-before heating plan, based on the DH forecast disclosed by companies, which considers fuel prices, operating and maintenance costs, hydraulic bottlenecks in the network, and other parameters. Moreover, the combined optimization of heat and power generation is aimed at providing maximum economic efficiency for the whole system. Each day, adaptation of the heating system is done, based on the consumption forecast, capacities, and power costs.

The main goals for DH systems approved by the Danish Government concern net-zero emissions of carbon dioxide by 2050 and fossil-independent DH systems before the year 2050 [118].

\subsection{Sweden}

DH systems were introduced in Sweden in 1948 [119]. District heating is a large industry in Sweden, satisfying about $50.4 \%$ of heat demand in the residential sector, according to data from 2017 [120]. The major competition for DH is using individual heat pumps, which, in 2014, constituted about $25 \%$ of the market share. Swedish DH systems may be classified as a 3rd generation DH system, regarding their temperature levels. Recently, average distribution temperatures have been $86^{\circ} \mathrm{C}$ for supply pipes and $47^{\circ} \mathrm{C}$ for return pipes [119]. Nowadays, about two-thirds of the heat supply to DH is based on biomass and waste heat, which is exceptional among high-income countries. Sweden was probably the first country that utilized industrial waste heat, and nowadays it is a country with the highest percentage share of industrial waste heat recovery. In 2015, waste heat represented about $8 \%$ of the total energy supplied to Swedish DH [121]. The idea presented in a case study performed by Brange et al. [5] in the Hyllie area in Malmö, Sweden, concerned DH prosumers-customers who both use and supply energy. The excess heat might be directly used in the $\mathrm{DH}$ network, or the temperature may be raised with a heat pump. According to obtained data for the Hyllie region, about $50 \%$ of the annual heat demand could be covered by prosumer heat. However, the majority of the excess heat is generated during the summer season; thus, thermal storage systems are required. Sweden supports the construction of "near-zero energy buildings". The case study described by Joly et al. [19] presents the approach, combining a near-zero energy house with a solar-assisted $100 \%$ renewable heating solution in the residential area of "Vallda Heberg" in Kungsbacka, Sweden. Extruded polyethylene insulated pipes are used as a more economic and technically preferable solution, in comparison to traditional steel pipes. The solar installation is able to produce $37 \%$ of the thermal energy requirement. 
The Swedish parliament has set, as a goal for the country, the attainment of a carbon dioxide-neutral state by the year 2045. Additionally, total energy use per heated area in Swedish buildings should be 50\% lower by 2050 (compared to levels from 1995) [122,123].

\subsection{Finland}

In 2017 , about $38 \%$ of heat demand was supplied by district heating systems in Finland [124]. The temperature of district heating water in the supply pipe changes according to the weather conditions and varies from 65 to $115^{\circ} \mathrm{C}$ for the supply and from 40 to $60{ }^{\circ} \mathrm{C}$ for the return; thus, the DHS might be classified as a 2 nd or 3rd generation system [125]. In 2016, the main DH resources in 2016 were coal and wood-derived fuels, and now about $80 \%$ of DH is produced by CHP [126]. However, coal-fired heat generation will be prohibited from May 2029 [127]. In 2016, the utilization of renewable energy sources amounted to $32 \%$, while, in 2018, this amount increased to $55 \%$. Nowadays, Finland has the third highest share, after Sweden and Latvia, of renewable energy in the DHC sector in the European Union [128]. Recently, heat pumps and utilization of industrial waste heat on a large scale became a promising source for Finnish DH [129]. The growing interest in large HPs in Finnish DH systems has been considered according to data provided by Kontu et al. [130]. The heat pumps in Finland have a potential of $10-25 \%$ of DH sales (while currently it is about $3 \%$ ). The analysis revealed that HP has the highest potential in small DH systems for replacing fossil fuel-fired boilers. Wahlroos et al. [131] investigated the possibility of using waste heat for Finnish DH systems in Espoo. The utilization of the waste heat led to savings in the total operational costs of the DH systems of between $0.6 \%$ and $7.3 \%$. Therefore, from an economic, environmental, and technical point of view, it is a sustainable solution. In Finland, one important future solution for the replacement of fossil fuel is the use of nuclear power as a heat source, resulting in a major reduction of pollutant emissions. The potential of small modular nuclear reactors (SMR) for $\mathrm{CO}_{2-}$ free DH production has been evaluated. The case study by Varri and Syri [132] includes application of NuScale SMR reactors with a total heat capacity of $300 \mathrm{MWdh}$ in the Helsinki region. Teräsvirta et al. [133] investigated replacing biomass cogeneration plants using heat-only small modular reactors of 24-200 MW for a mid-sized city in eastern Finland. The most promising solution assumed the use of five $24 \mathrm{MW}$ heat-only SMR units combined with a $100 \mathrm{MWt}$ cogeneration plant. Both studies confirmed that the application of SMR might be profitable. However, the hesitance concerns the investment costs for rising SMR technologies.

A new interesting trend in Finland is solar heating. In Finland, most of the community lives in regions that reach above $5.3 \mathrm{GJ} / \mathrm{m}^{2}$ total solar radiation per year [134]. The seasonal storage of solar heat is crucial in solar district heating plants as a solution to the mismatch between energy supply and demand. According to Rehman et al. [134], Finland is located in an area suitable for borehol TES (BTES). One of the examples of an early large-scale, high-temperature solar-heating system with seasonal storage of energy was constructed in Finland is the Kerava solar village [135]. The total heat demand of the community, including 44 apartments with flat-plate solar panels, was $495 \mathrm{MWh}$ annually. Considering heat loss, the solar heating system was planned to produce $550 \mathrm{MWh}$ per year. The borehole TES is a combined system using 54 tilted boreholes filled with water. The holes provide layered thermal storage, with a water temperature of $55-65^{\circ} \mathrm{C}$ at the top and $8{ }^{\circ} \mathrm{C}$ at the bottom during the winter season. The top water may be applied for short-term storage or for household hot water generation. Moreover, aquifer thermal energy storage (ATES), combined with ground-source heat pumps (GSHP), is considered to be an attractive technology for Finnish DHS. The case study was performed by Todorov et al. [128] for the integration of ATES-GSHP into the existing DH system in the Finnish Urban District. The use of a pre-cooling exchanger led to an increase in the heating and cooling demand covered by ATES of $13 \%$ and 15\%, respectively. Furthermore, a decrease in the heat generation cost by $5.2 \%$ has been reported. 


\subsection{Lithuania}

Lithuania has a well-developed DH system. The heating season in Lithuania starts when the outdoor temperatures, after three consecutive days, are below $+10{ }^{\circ} \mathrm{C}$. Nowadays, the heating season lasts from October until April [136]. Meanwhile, heat demand for domestic heating is almost 1.8 times higher in Lithuania in comparison to other EU countries with comparable weather conditions [137]. According to data in 2017, DH satisfied about $56 \%$ of heat demand in the residential sector [138]. Other Lithuanian households use individual heating systems, fed with firewood, natural gas, coal, or oil products as fuel [139].

According to the literature, Lithuania's potential for solar energy production is approximately $1000 \mathrm{kWh} / \mathrm{m}^{2}$ per year. The daily potential is variable depending on the season, from about $0.55 \mathrm{kWh}$ in January to $5.8 \mathrm{kWh}$ in June [140]. Nowadays, the potential of solar heat energy generation in Lithuania reaches $1.5 \mathrm{TWh} /$ year [140] and, up until 2016, about $14800 \mathrm{~m}^{2}$ of solar collectors were installed in the country, while the application refers mainly to a single-family houses [141].

Šliaupa et al. [142] noted that Lithuania contains large hydro-geothermal resources, mainly in the largest Cambrian, Lower Devonian, and Upper-Middle Devonian reservoirs. Despite very good geothermal conditions, there is only the Klaipeda geothermal district heating plant in Lithuania, which was opened in 2001. However, in 2017, due to decreasing injectivity, the operation of the plant was ceased.

Lithuania's national goal is to produce heat with zero $\mathrm{CO}_{2}$ emissions by the year 2050 . The National Energy Independence Strategy of the Republic of Lithuania, accepted in 2018, assumed a goal to increase the RES share in final energy consumption by up to $30 \%$ by 2020 , $45 \%$ by 2030 , and $80 \%$ by 2050 [143]. Furthermore, Lithuania's energy strategy is to promote the development of DH systems and cogeneration plants and to start district cooling of buildings. According to Kveselis et al. [144], Lithuania shows a positive trend towards the fulfillment of these energy goals. The most significant factors stimulating the progress of $\mathrm{DH}$ in Lithuania include international responsibilities to enhance the participation of CHP plants using RES in energy generation and the development of small CHP plants, as well as the establishment of an energy strategy that supports the use of renewable energy sources in DH systems. Based on the research performed by Šiupšinskas and Rogoža [145], in Lithuania, DH systems have been combined with renewable energy sources; biomass and solar energy are environmentally favorable solutions for heat production. The utilization of these sources may help the country to reach nearly zero $\mathrm{CO}_{2}$ emissions.

\subsection{Germany}

In 2017, DH satisfied about $14-24 \%$ of heat demand in the residential sector (for existing buildings, while it is about $44 \%$ for newly built houses) [146,147]. Currently, more than $80 \%$ of district heating in Germany is generated by CHP generation [147]. However, in 2017, the share of renewable energy in district heating consumption in Germany was only $12 \%$, including energy from biomass and geothermal sources [147]. Additionally, a significant source is MSW energy, which, in 2017, reached $11.6 \%$, while waste industrial energy constituted about $2 \%$ of the share [147]. An essential aspect of German DH is also geothermal energy. Thirty geothermal plants in Germany generate about $155 \mathrm{GWh}$ of electricity and 1.3 TWh of heat, annually [148].

Petersen [149] described the idea of self-supplying communities based on local and renewable energy sources. A case study using oat peel biomass CHP in the community of Krückau-Vormstegen in Elmshorn, Germany, was developed. For the investigated community, the local heating energy potential based on renewable energies is up to $44.64 \mathrm{GWh}$ /year. This surpasses the local heating demand, ranging between 4.22 and $8.42 \mathrm{GWh} /$ year. However, the implementation process of this approach might be timeconsuming and will require initial investment and operational costs.

Pelda et al. [150] analyzed the potential for Germany to incorporate waste industrial heat and solar thermal energy into DH systems. The obtained results showed that solar ther- 
mal energy and waste industrial heat potential have been used only to a very limited extent. The calculated theoretical potential of solar thermal power is about $377 \times 10^{3} \mathrm{TWh} /$ year, and the theoretical potential of waste heat from the industry sector is between $43 \mathrm{TWh} /$ year and $193 \mathrm{TWh}$ /year. Thus, implementation of both strategies into DH systems might significantly reduce $\mathrm{CO}_{2}$ emissions. However, according to the predictions of the German industry association for district heating and cooling, solar thermal systems with $800,000 \mathrm{~m}^{2}$ of collector field area in the district heating systems exist in 2020 in Germany [151].

Germany has several seasonal thermal energy storage systems (STES), especially tank thermal energy storage (TTES) and water gravel thermal energy storage (WGTES). Additionally, four aquifer thermal energy storages (ATES) exist in Germany. The investigation performed by Schüppler et al. [152] evaluated the techno-economic and environmental impact of the developed ATES in Karlsruhe. The examined ATES has a cooling capacity of 3.0 MW and a heating capacity of $1.8 \mathrm{MW}$. The most productive supply preference is that the direct cooling by the ATES results in a decrease in electricity cost of $80 \%$. Moreover, concerning the reference system, the ATES achieves $\mathrm{CO}_{2}$ savings of around 600 tons annually.

The scenario is to achieve a $100 \%$ renewable German energy system by 2050 . The energy transition concept of Germany specifies the reduction of $\mathrm{CO}_{2}$ emissions by $40 \%$ by $2020,55 \%$ by 2030 , and at least $80 \%$ by the year 2050, compared with the year 1990 . To achieve these goals, according to Hansen et al. [20], DH systems in Germany should comply with the following requirements: increase the expansion and share of $\mathrm{DH}$ for heat demand, heat savings, and increase the number of individual heat pumps.

\subsection{Latvia}

In Latvia, the duration of the heating season exceeds half a year; thus, high-quality heat supply is needed. In 2015, the share of DH in Latvia satisfied about $30 \%$ of the residential sector [153]. Most of the heat energy is produced by boiler houses and CHP plants (the share of CHP in DH generation according to data from 2019 was 73\%) [154]. DH is mostly charged by natural gas and biomass (renewables constitute about $47-50 \%$ of energy source [155]. However, the goal is to increase the share of renewable energy sources in DH to $60 \%$ by 2023 [156].

In 2019, the first large-scale solar district heating plant was opened in Salaspis, Latvia [157]. The plant includes 1720 collectors, can generate about 12,000 kWh of power per year, and is the biggest solar DH installation in Europe. Moreover, the plant is equipped with a $28 \mathrm{~m}$ high storage tank and a 3MW wood chip boiler.

Povilanskas et al. [158] analyzed Latvia's potential for using geothermal energy for DH systems. The case study involved Nìca, a small municipality in southwest Latvia. The investigation revealed that the temperature of the Lower Cambrian sandy siltstone aquifer was confirmed to be not less than $43^{\circ} \mathrm{C}$, and it was possible to obtain about $2 \mathrm{l} / \mathrm{s}$ of the hot brine to provide sufficient heat to the DHS of Nica throughout the year. The authors stated that three main requirements had to be met to reach high efficiency. These were the satisfactory extractable heat resources of the aquifer, immediate availability of a nearby deep well, and a plan for the environmentally acceptable transfer of the cooled geothermal water to the surface waters.

The majority of the DH grids work in 2nd and 3rd generation temperature regimes [159]. However, according to the analysis by Ziemele et al. [160], the transition to 4th generation $\mathrm{DH}$ is possible in Latvia and could provide a $68 \%$ share of RES, and the heat tariff could be reduced by $48 \%$ until 2030. Moreover, $\mathrm{CO}_{2}$ emissions could be reduced by $58 \%$ by 2030. The pilot case study performed by Feofilovs et al. [161] confirmed that transition to low-temperature district heating (LTDH) with Solar PV will improve the environmental performance of $\mathrm{DH}$; however, significant modernization or reconstruction will be required, including changes of valves, pipelines, insulations, and boiler houses to improve the heat production effectiveness. However, Cirule et al. [162] suggested that legislation in Latvia does not provide a proper basis to develop or safeguard 4th generation DH. The authors 
pointed out that it is necessary to raise the competitiveness of the DH system in comparison to other heating solutions, thereby making DH systems more interesting for consumers.

Independence from fossil fuel and the reduction of carbon dioxide emissions by $80-95 \%$ by 2050 compared to 1990 levels are the main targets for the Latvian community [156].

\section{Conclusions and Recommendations for Future Research}

Nowadays, according to European Union regulations, the DH Sector in the Baltic Sea Region countries is constantly undergoing a transition related to increasing the share of renewable energy sources and the reduction of greenhouse gases emissions. From an economic point of view, DH companies strive for an increase in heat supply efficiency, becoming unrivaled, and extending the number of customers. Thus, the intention to establish 4th generation DH systems is fully justified. Lowering the temperature of the water supply, integration of RES such as solar, thermal, wind, or geothermal energy, and application of better insulated and optimized pipeline layouts are significant steps towards improving the effectiveness of current DH systems. Moreover, the introduction of smart management tools into DH systems may overcome both the challenges in existing $\mathrm{DH}$ networks and be an essential aspect to ensure profitability for both heat producers and consumers. Intelligent networks with demand site management are an inherent part of DHS development and could have advantages in providing safe and efficient DH systems. Nowadays, implementation of the SAM concept in the $\mathrm{DH}$ sector mostly involves the forecasting of heat supply and demand-side management, which may significantly reduce the amount of energy used for heating. However, in the current state-of-the-art, there is a key research gap in the application of smart predictive and preventive methods for $\mathrm{DH}$ network performance control and maintenance. An interesting approach of future research may be related to the development of novel smart methods to predict and detect possible failures and damages, minimize the risk of failures, and introduce a system of preventive response. Future studies may examine and model the techno-economic aspects of SAM. A clear indication of the SAM solution's competitiveness in the $\mathrm{DH}$ sector is also needed. Moreover, the design and development of innovative multi-source DH systems instead of them being charged by a single fuel type should be proposed. This solution should lead to the heat demand being covered and the ability to select a preferable heat source at any given time, as well as the capability to maintain a continuous heat supply when one of the sources fails. Furthermore, an important aspect is assuring the sustainable development of DH systems, especially related to thermal energy storage. Research is proposed in the area of more dynamic prosumer involvement and the development of bi-directional DHC networks. Implementation of these solutions may help to reduce $\mathrm{CO}_{2}$ emissions as well as energy costs in the near future.

Author Contributions: Conceptualization, P.R., A.G., and A.R.; writing-original draft preparation, A.G., P.R., and J.S.; formal analysis, A.R. and V.L., technical consultation, V.L.; writing-review and editing, P.R. and A.G.; funding acquisition, A.R. All authors have read and agreed to the published version of the manuscript.

Funding: This research received no external funding.

Institutional Review Board Statement: Not applicable.

Informed Consent Statement: Not applicable.

Data Availability Statement: Data available in a publicly accessible repository as well as in a publicly accessible repository that does not issue DOIs. All data referred to in this paper are accessible according to the list of references.

Acknowledgments: This manuscript was prepared within a scope of a Baltic smart asset management (BSAM) project, co-financed by the Interreg South Baltic Program 2014-2020.

Conflicts of Interest: The authors declare no conflict of interest. 


\section{References}

1. Van Dongen, L.A.M.; Frunt, L.; Martinetti, A. Smart Asset Management or Smart Operation Management? The Netherlands Railways Case. In Transportation Systems; Singh, S., Martinetti, A., Majumdar, A., van Dongen, L.A.M., Eds.; Springer: Singapore, 2019; pp. 113-132. [CrossRef]

2. Gao, L.; Cui, X.; Ni, J.; Lei, W.; Huang, T.; Bai, C.; Yang, J. Technologies in Smart District Heating System. Energy Procedia 2017, 142, 1829-1834. [CrossRef]

3. Dahash, A.; Ochs, F.; Tosatto, A.; Streicher, W. Toward efficient numerical modeling and analysis of large-scale thermal energy storage for renewable district heating. Appl. Energy 2020, 279, 115840. [CrossRef]

4. Bünning, F.; Wetter, M.; Fuchs, M.; Müller, D. Bidirectional low temperature district energy systems with agent-based control: Performance comparison and operation optimization. Appl. Energy 2018, 502-515. [CrossRef]

5. Brange, L.; Englund, J.; Lauenburg, P. Prosumers in district heating networks-A Swedish case study. Appl. Energy 2016, 164, 492-500. [CrossRef]

6. Guelpa, E.; Verda, V. Demand Response and other Demand Side Management techniques for District Heating: A review. Energy 2020, 119440. [CrossRef]

7. Kristensen, M.; Hedegaard, R.; Petersen, S. Long-term forecasting of hourly district heating loads in urban areas using hierarchical archetype modeling. Energy 2020, 201, 117687. [CrossRef]

8. Sarafraz, M.M.; Tlili, I.; Tian, Z.; Bakouri, M.; Safaei, M.R. Smart optimization of a thermosyphon heat pipe for an evacuated tube solar collector using response surface methodology (RSM). Physica A 2019, 534, 122146. [CrossRef]

9. Sarafraz, M.M.; Tlili, I.; Tian, Z.; Bakouri, M.; Safaei, M.R.; Goodarzi, M. Thermal Evaluation of Graphene Nanoplatelets Nanofluid in a Fast-Responding HP with the Potential Use in Solar Systems in Smart Cities. Appl. Sci. 2019, 9, 2101. [CrossRef]

10. Sarafraz, M.M.; Tlili, I.; Baseer, M.A.; Safaei, M.R. Potential of Solar Collectors for Clean Thermal Energy Production in Smart Cities using Nanofluids: Experimental Assessment and Efficiency Improvement. Appl. Sci. 2019, 8, 1877. [CrossRef]

11. Hong, M.S.; Young-Shin, J.; Woo-Cheol, K.; Joon, J.C.; Jung-Gu, K. Optimization of Cathodic Protection System for RiverCrossing District Heating Pipeline using Computational Analysis: Part I. The Basic Model. Int. J. Electrochem. Sci. 2020, 15, 7013-7026. [CrossRef]

12. Mandley, S.J.; Daioglou, V.; Junginger, H.M.; van Vuuren, D.P.; Wicke, B. EU bioenergy development to 2050. Renew. Sustain. Energy Rev. 2020, 127, 109858. [CrossRef]

13. Hast, A.; Syri, S.; Lekavičius, V.; Galinis, A. District heating in cities as a part of low-carbon energy system. Energy 2018, 152, 627-639. [CrossRef]

14. Buffa, S.; Cozzini, M.; D'Antoni, M.; Baratieri, M.; Fedrizzi, R. 5th generation district heating and cooling systems: A review of existing cases in Europe. Renew. Sustain. Energy Rev. 2019, 104, 504-522. [CrossRef]

15. Sayegh, M.A.; Danielewicz, J.; Nannou, T.; Miniewicz, M.; Jadwiszczak, P.; Piekarska, K.; Jouhara, H. Trends of European research and development in district heating technologies. Renew. Sustain. Energy Rev. 2017, 68, 1183-1192. [CrossRef]

16. Köfinger, M.; Schmidt, R.R.; Basciotti, D.; Terreros, O.; Baldvinsson, I.; Mayrhofer, J.; Moser, S.; Tichler, R.; Pauli, H. Simulation based evaluation of large scale waste heat utilization in urban district heating networks: Optimized integration and operation of a seasonal storage. Energy 2018, 159, 1161-1174. [CrossRef]

17. Sun, L.; Fujii, M.; Tasaki, T.; Dong, H.; Ohnishi, S. Improving waste to energy rate by promoting an integrated municipal solid-waste management system. Resour. Conserv. Recycl. 2018, 136, 289-296. [CrossRef]

18. Francisco Pinto, J.; Carrilho da Graça, G. Comparison between geothermal district heating and deep energy refurbishment of residential building districts. Sustain. Cities Soc. 2018, 38, 309-324. [CrossRef]

19. Joly, M.; Ruiz, G.; Mauthner, F.; Bourdoukan, P.; Emery, M.; Anderson, M. A methodology to integrate solar thermal energy in district heating networks confronted with a Swedish real case study. Energy Procedia 2017, 122, 865-870. [CrossRef]

20. Hansen, K.; Mathiesen, B.V.; Skov, I.R. Full energy system transition towards $100 \%$ renewable energy in Germany in 2050 . Renew. Sustain. Energy Rev. 2019, 102, 1-13. [CrossRef]

21. Dong, J.; Tang, Y.; Nzihou, A.; Chi, Y. Key factors influencing the environmental performance of pyrolysis, gasification and incineration Waste-to-Energy technologies. Energy Convers. Manag. 2019, 196, 497-512. [CrossRef]

22. Simeoni, P.; Ciotti, G.; Cottes, M.; Meneghetti, A. Integrating industrial waste heat recovery into sustainable smart energy systems. Energy 2019, 175, 941-951. [CrossRef]

23. Tsai, W.T. Analysis of municipal solid waste incineration plants for promoting power generation efficiency in Taiwan. J. Mater. Cycles Waste Manag. 2016, 18, 393-398. [CrossRef]

24. Rudra, S.; Tesfagaber, Y.K. Future district heating plant integrated with municipal solid waste (MSW) gasification for hydrogen production. Energy 2019, 180, 881-892. [CrossRef]

25. Jonynas, R.; Puida, E.; Poškas, R.; Paukštaitis, L.; Jouhara, H.; Gudzinskas, J.; Miliauskas, G.; Lukoševičius, V. Renewables for district heating: The case of Lithuania. Energy 2020, 211, 119064. [CrossRef]

26. Hendricks, A.M.; Wagner, J.E.; Volk, T.A.; Newman, D.H.; Brown, T.R. A cost-effective evaluation of biomass district heating in rural communities. Appl. Energy 2016, 162, 561-569. [CrossRef]

27. Sartor, K.; Dewallef, P. Integration of heat storage system into district heating networks fed by a biomass CHP plant. J. Energy Storage 2018, 15, 350-358. [CrossRef] 
28. Quirion-Blais, O.; Malladi, K.T.; Sowlati, T.; Gao, E.; Mui, C. Analysis of feedstock requirement for the expansion of a biomass-fed district heating system considering daily variations in heat demand and biomass quality. Energy Convers. Manag. 2019, 187, 554-564. [CrossRef]

29. Ericsson, K.; Werner, S. The introduction and expansion of biomass use in Swedish district heating systems. Biomass Bioenergy 2016, 94, 57-65. [CrossRef]

30. Kucharska, K.; Rybarczyk, P.; Hołowacz, I.; Konopacka-Łyskawa, D.; Słupek, E.; Makoś, P.; Ciesliński, H.; Kamiński, M. Influence of alkaline and oxidative pre-treatment of waste corn cobs on biohydrogen generation efficiency via dark fermentation. Biomass Bioenergy 2020, 141, 105691. [CrossRef]

31. Karimi Alavijeh, M.; Yaghmaei, S. Biochemical production of bioenergy from agricultural crops and residue in Iran. Waste Manag. 2016, 52, 375-394. [CrossRef]

32. García-Velásquez, C.A.; Cardona, C.A. Comparison of the biochemical and thermochemical routes for bioenergy production: A techno-economic (TEA), energetic and environmental assessment. Energy 2019, 172, 232-242. [CrossRef]

33. Clausen, L.R. Energy efficient thermochemical conversion of very wet biomass to biofuels by integration of steam drying, steam electrolysis and gasification. Energy 2017, 125, 327-336. [CrossRef]

34. Shahbaz, M.; Yusup, S.; Inayat, A.; Patrick, D.O.; Partama, A. System analysis of poly-generation of SNG, power and district heating from biomass gasification system. Chem. Eng. Trans. 2016, 52, 781-786. [CrossRef]

35. Wang, J.; Wang, Z.; Zhou, D.; Sun, K. Key issues and novel optimization approaches of industrial waste heat recovery in district heating systems. Energy 2019, 188, 116005. [CrossRef]

36. Xu, Z.Y.; Wang, R.Z.; Yang, C. Perspectives for low-temperature waste heat recovery. Energy 2019, 176, 1037-1043. [CrossRef]

37. Dagilis, V.; Vaitkus, L.; Balcius, A.; Gudzinskas, J.; Lukoševičius, V. Grade heat recovery system for woodfuel cogeneration plant using water vapour regeneration. Therm. Sci. 2018, 22, 2667-2677. [CrossRef]

38. Fang, H.; Xia, J.; Jiang, Y. Key issues and solutions in a district heating system using low-grade industrial waste heat. Energy 2015, 86, 589-602. [CrossRef]

39. Fitó, J.; Hodencq, S.; Ramousse, J.; Wurtz, F.; Stutz, B.; Debray, F.; Vincent, B. Energy- and exergy-based optimal designs of a low-temperature industrial waste heat recovery system in district heating. Energy Convers. Manag. 2020, 211, 112753. [CrossRef]

40. Lund, J.W. Development and utilization of geothermal resources. In Proceedings of the ISES World Congress 2007, Beijing, China, 18-21 September 2007; Volume 1, pp. 87-95. [CrossRef]

41. Chen, Y.; Wang, J.; Lund, P.D. Sustainability evaluation and sensitivity analysis of district heating systems coupled to geothermal and solar resources. Energy Convers. Manag. 2020, 220, 113084. [CrossRef]

42. Geothermal Energy. Available online: http://www.geothermaleranet.is/about-geothermal-era-net/geothermal-energy-/ (accessed on 10 September 2020).

43. Dumas, P. A European perspective of the development of deep geothermal in urban areas: Smart thermal grids, geothermal integration into smart cities. Geomech. Tunnelbau 2016, 9, 447-450. [CrossRef]

44. Weiss, W.; Spörk-Dür, M. Solar Heat Worldwide 2018. Global Market Development and Trends in 2017. Detailed Market Figures 2016. IEA Sol. Heat. Cool. Program. 2018, 94. [CrossRef]

45. Chung, K.M.; Chen, C.C.; Chang, K.C. Effect of diffuse solar radiation on the thermal performance of solar collectors. Case Stud. Therm. Eng. 2018, 12, 759-764. [CrossRef]

46. Huang, J.; Fan, J.; Furbo, S. Feasibility study on solar district heating in China. Renew. Sustain. Energy Rev. 2019, 108, 53-64. [CrossRef]

47. Lund, H.; Werner, S.; Wiltshire, R.; Svendsen, S.; Thorsen, J.E.; Hvelplund, F.; Mathiesen, B.V. 4th Generation District Heating (4GDH). Integrating smart thermal grids into future sustainable energy systems. Energy 2014, 68, 1-11. [CrossRef]

48. Millar, M.A.; Burnside, N.M.; Yu, Z. District heating challenges for the UK. Energies 2019, 12, 310. [CrossRef]

49. Averfalk, H.; Werner, S. Economic benefits of fourth generation district heating. Energy 2020, 193, 116727. [CrossRef]

50. Askeland, K.; Rygg, B.J.; Sperling, K. The role of 4th generation district heating (4GDH) in a highly electrified hydropower dominated energy system-The case of Norway. Int. J. Sustain. Energy Plan. Manag. 2020, 27, 17-34. [CrossRef]

51. Li, H.; Nord, N. Transition to the 4th generation district heating-Possibilities, bottlenecks, and challenges. Energy Procedia 2018, 149, 483-498. [CrossRef]

52. Ziemele, J.; Cilinskis, E.; Blumberga, D. Pathway and restriction in district heating systems development towards 4th generation district heating. Energy 2018, 152, 108-118. [CrossRef]

53. Schweiger, G.; Kuttin, F.; Posch, A. District heating systems: An analysis of strengths, weaknesses, opportunities, and threats of the 4GDH. Energies 2019, 12, 4748. [CrossRef]

54. Revesz, A.; Jones, P.; Dunham, C.; Davies, G.; Marques, C.; Matabuena, R.; Scott, J.; Maidment, G. Developing novel 5th generation district energy networks. Energy 2020, 201, 117389. [CrossRef]

55. Wirtz, M.; Kivilip, L.; Remmen, P.; Müller, D. 5th Generation District Heating: A novel design approach based on mathematical optimization. Appl. Energy 2020, 260, 114158. [CrossRef]

56. von Rhein, J.; Henze, G.P.; Long, N.; Fu, Y. Development of a topology analysis tool for fifth-generation district heating and cooling networks. Energy Convers. Manag. 2019, 196, 705-716. [CrossRef]

57. Boesten, S.; Ivens, W.; Dekker, S.C.; Eijdems, H. 5th Generation District Heating and Cooling Systems as a Solution for Renewable Urban Thermal Energy Supply. Adv. Geosci. 2019, 49, 129-136. [CrossRef] 
58. Li, H.; Wang, S.J. Challenges in smart low-T emperature district heating development. Energy Procedia 2014, 61, 1472-1475. [CrossRef]

59. Månsson, S.; Johansson Kallioniemi, P.O.; Thern, M.; Van Oevelen, T.; Sernhed, K. Faults in district heating customer installations and ways to approach them: Experiences from Swedish utilities. Energy 2019, 180, 163-174. [CrossRef]

60. Gustafsson, J.; Sandin, F. District Heating Monitoring and Control Systems; Elsevier Ltd.: Amsterdam, The Netherlands, 2015; ISBN 9781782423959.

61. Turski, M.; Nogaj, K.; Sekret, R. The use of a PCM heat accumulator to improve the efficiency of the district heating substation. Energy 2019, 187. [CrossRef]

62. Masatin, V.; Latõšev, E.; Volkova, A. Evaluation Factor for District Heating Network Heat Loss with Respect to Network Geometry. Energy Procedia 2016, 95, 279-285. [CrossRef]

63. Yarahmadi, N.; Sällström, J.H. Improved maintenance strategies for district heating pipe-lines. In Proceedings of the 14th International Symposium on District Heating and Cooling, Stockholm, Sweden, 6-10 September 2014.

64. Franco, A.; Bellina, F. Methods for optimized design and management of CHP systems for district heating networks (DHN). Energy Convers. Manag. 2018, 172, 21-31. [CrossRef]

65. Brange, L.; Englund, J.; Sernhed, K.; Thern, M.; Lauenburg, P. Bottlenecks in district heating systems and how to address them. Energy Procedia 2017, 116, 249-259. [CrossRef]

66. Brange, L.; Lauenburg, P.; Sernhed, K.; Thern, M. Bottlenecks in district heating networks and how to eliminate them-A simulation and cost study. Energy 2017, 137, 607-616. [CrossRef]

67. Sattar, A.M.; Chaudhry, M.H.; Kassem, A.A. Partial blockage detection in pipelines by frequency response method. J. Hydraul. Eng. 2008, 134, 76-89. [CrossRef]

68. Zhou, S.; O'Neill, Z.; O'Neill, C. A review of leakage detection methods for district heating networks. Appl. Therm. Eng. 2018, 137, 567-574. [CrossRef]

69. Mohapatra, P.K.; Chaudhry, M.H.; Kassem, A.A.; Moloo, J. Detection of partial blockage in single pipelines. J. Hydraul. Eng. 2006, 132, 200-206. [CrossRef]

70. Heating and Cooling. Available online: https://ec.europa.eu/energy/topics/energy-efficiency/heating-and-cooling_en (accessed on 10 September 2020).

71. Greenhous Gas Emissions. Available online: https://www.eea.europa.eu/airs/2018/resource-efficiency-and-low-carboneconomy / greenhouse-gas-emission (accessed on 10 September 2020).

72. Yang, X.; Li, H.; Svendsen, S. Decentralized substations for low-temperature district heating with no Legionella risk, and low return temperatures. Energy 2016, 110, 65-74. [CrossRef]

73. Yang, X.; Li, H.; Svendsen, S. Alternative solutions for inhibiting Legionella in domestic hot water systems based on lowtemperature district heating. Build. Serv. Eng. Res. Technol. 2016, 37, 468-478. [CrossRef]

74. Li, Y.; Rezgui, Y.; Zhu, H. District heating and cooling optimization and enhancement-Towards integration of renewables, storage and smart grid. Renew. Sustain. Energy Rev. 2017, 72, 281-294. [CrossRef]

75. Zarin Pass, R.; Wetter, M.; Piette, M.A. A thermodynamic analysis of a novel bidirectional district heating and cooling network. Energy 2018, 144, 20-30. [CrossRef]

76. Postnikov, I.; Stennikov, V.; Penkovskii, A. Prosumer in the district heating systems: Operating and reliability modeling. Energy Procedia 2019, 158, 2530-2535. [CrossRef]

77. van der Heijde, B.; Vandermeulen, A.; Salenbien, R.; Helsen, L. Integrated optimal design and control of fourth generation district heating networks with thermal energy storage. Energies 2019, 12, 2766. [CrossRef]

78. Tang, R.; Wang, S. Model predictive control for thermal energy storage and thermal comfort optimization of building demand response in smart grids. Appl. Energy 2019, 242, 873-882. [CrossRef]

79. Guelpa, E.; Marincioni, L. Demand side management in district heating systems by innovative control. Energy 2019, 188, 116037. [CrossRef]

80. Wang, Z.; Crawley, J.; Li, F.G.N.; Lowe, R. Sizing of district heating systems based on smart meter data: Quantifying the aggregated domestic energy demand and demand diversity in the UK. Energy 2020, 193, 116780. [CrossRef]

81. Guelpa, E.; Marincioni, L.; Deputato, S.; Capone, M.; Amelio, S.; Pochettino, E.; Verda, V. Demand side management in district heating networks: A real application. Energy 2019, 182, 433-442. [CrossRef]

82. Idowu, S.; Saguna, S.; Åhlund, C.; Schelén, O. Applied machine learning: Forecasting heat load in district heating system. Energy Build. 2016, 133, 478-488. [CrossRef]

83. Guelpa, E.; Marincioni, L.; Capone, M.; Deputato, S.; Verda, V. Thermal load prediction in district heating systems. Energy 2019, 176, 693-703. [CrossRef]

84. Kontu, K.; Vimpari, J.; Penttinen, P.; Junnila, S. City scale demand side management in three different-sized district heating systems. Energies 2018, 11, 3370. [CrossRef]

85. Wang, H.; Wang, H.; Haijian, Z.; Zhu, T. Optimization modeling for smart operation of multi-source district heating with distributed variable-speed pumps. Energy 2017, 138, 1247-1262. [CrossRef]

86. Wang, H.; Wang, H.; Zhou, H.; Zhu, T. Modeling and optimization for hydraulic performance design in multi-source district heating with fluctuating renewables. Energy Convers. Manag. 2018, 156, 113-129. [CrossRef]

87. Lu, S.; Gu, W.; Zhou, J.; Zhang, X.; Wu, C. Coordinated dispatch of multi-energy system with district heating network: Modeling and solution strategy. Energy 2018, 152, 358-370. [CrossRef] 
88. Zaporozhets, A.; Eremenko, V.; Serhiienko, R.; Ivanov, S. Methods and Hardware for Diagnosing Thermal Power Equipment Based on Smart Grid Technology; Springer International Publishing: Berlin/Heidelberg, Germany, 2019; Volume 871, ISBN 9783030010683.

89. De Lorenzi, A.; Gambarotta, A.; Morini, M.; Rossi, M.; Saletti, C. Setup and testing of smart controllers for small-scale district heating networks: An integrated framework. Energy 2020, 205, 118054. [CrossRef]

90. Novitsky, N.N.; Shalaginova, Z.I.; Alekseev, A.A.; Tokarev, V.V.; Grebneva, O.A.; Lutsenko, A.V.; Vanteeva, O.V.; Mikhailovsky, E.A.; Pop, R.; Vorobev, P.; et al. Smarter Smart District Heating. Proc. IEEE 2020, 108, 1596-1611. [CrossRef]

91. Vivian, J.; Jobard, X.; Hassine, I.B.; Hurink, J. Smart Control of a District Heating Network with High Share of Low Temperature Waste Heat Direct Use of Low Temperature Heat in District Heating Networks with Booster Heat Pumps View project i_city: Intelligent city View project. In Proceedings of the 12th Conference on Sustainable Development of Energy, Water and Environmental Systems-SDEWES, Dubrovnik, Croatia, 4-8 October 2017.

92. Zhong, Y.; Xu, Y.; Wang, X.; Jia, T.; Xia, G.; Ma, A.; Zhang, L. Pipeline leakage detection for district heating systems using multisource data in mid- and high-latitude regions. ISPRS J. Photogramm. Remote Sens. 2019, 151, 207-222. [CrossRef]

93. Ahn, J.; Cho, S. Development of an intelligent building controller to mitigate indoor thermal dissatisfaction and peak energy demands in a district heating system. Build. Environ. 2017, 124, 57-68. [CrossRef]

94. Wang, H.; Meng, H.; Zhu, T. New model for onsite heat loss state estimation of general district heating network with hourly measurements. Energy Convers. Manag. 2018, 157, 71-85. [CrossRef]

95. Smart Active Box. Available online: https://www.smartactivebox.com (accessed on 10 October 2020).

96. The Storm Controller. Available online: https://storm-dhc.eu/en/storm-controller (accessed on 10 October 2020).

97. Fifth Generation, Low Temperature, High EXergY District Heating and Cooling NETworkS. Available online: https: / / cordis. europa.eu/project/id/649820 (accessed on 10 October 2020).

98. Smart Heating-Danfoss Link. Available online: https://www.smartheating.danfoss.com/pl (accessed on 20 September 2020).

99. Vexve Has Developed the First Smart Valve Solution for Underground District Energy Networks. Available online: https: //www.vexve.com/ (accessed on 20 September 2020).

100. Ohlsson, M. Take Care of Your Network (Presentation). Available online: https://1sta.lt/wp-content/uploads/2020/09/3_ Magnus-Ohlsson.pdf (accessed on 20 November 2020).

101. Bestandsdaten und Schadensstatistik. Available online: www.agfw-bestand.online (accessed on 3 January 2021).

102. Wojdyga, K.; Chorzelski, M. Chances for Polish district heating systems. Energy Procedia 2017, 116, 106-118. [CrossRef]

103. District Energy in Poland. Available online: https://www.euroheat.org/knowledge-hub/district-energy-poland/ (accessed on 12 September 2020).

104. Polish District Heating Sector—From Coal to Solar? Available online: https:/ / www.euroheat.org/news/polish-district-heatingsector-coal-solar/ (accessed on 12 September 2020).

105. Burchard-Dziubińska, M. Air pollution and health in Poland: Anti-smog movement in the most polluted Polish cities. Ekon. Sr. 2019, 2, 76-90. [CrossRef]

106. Wojdyga, K. An influence of weather conditions on heat demand in district heating systems. Energy Build. 2008, 40, 2009-2014. [CrossRef]

107. Cenian, A.; Dzierzgowski, M.; Pietrzykowski, B. On the road to low temperature district heating. J. Phys. Conf. Ser. 2019, 1398. [CrossRef]

108. Zwierzchowski, R. Characteristics of large thermal energy storage systems in Poland. E3S Web Conf. 2017, 22. [CrossRef]

109. Kęińska, B. Geothermal Energy Use, Country Update for Poland, 2013-2015. In Proceedings of the EGC Proceedings, Strasbourg, France, 19-24 September 2016; pp. 1-10.

110. Kaczmarczyk, M. Potential of existing and newly designed geothermal heating plants in limiting of low emissions in Poland. E3S Web Conf. 2018, 44. [CrossRef]

111. Renewables in Heating. Available online: https://www.forum-energii.eu/en/analizy/oze-w-cieplownictwie (accessed on 1 September 2020).

112. Yang, X.; Li, H.; Svendsen, S. Energy, economy and exergy evaluations of the solutions for supplying domestic hot water from low-temperature district heating in Denmark. Energy Convers. Manag. 2016, 122, 142-152. [CrossRef]

113. District Energy in Denmark. Available online: https://www.euroheat.org/knowledge-hub/district-energy-denmark/ (accessed on 1 September 2020).

114. Tian, Z.; Zhang, S.; Deng, J.; Fan, J.; Huang, J.; Kong, W.; Perers, B.; Furbo, S. Large-scale solar district heating plants in Danish smart thermal grid: Developments and recent trends. Energy Convers. Manag. 2019, 189, 67-80. [CrossRef]

115. Bühler, F.; Petrović, S.; Karlsson, K.; Elmegaard, B. Industrial excess heat for district heating in Denmark. Appl. Energy 2017, 205, 991-1001. [CrossRef]

116. Lund, R.; Persson, U. Mapping of potential heat sources for heat pumps for district heating in Denmark. Energy 2016, 110, 129-138. [CrossRef]

117. Foteinaki, K.; Li, R.; Péan, T.; Rode, C.; Salom, J. Evaluation of energy flexibility of low-energy residential buildings connected to district heating. Energy Build. 2020, 213, 109804. [CrossRef]

118. Denmark's Integrated National Energy and Climate Plan. Available online: https://ec.europa.eu/energy/sites/ener/files/ documents/dk_final_necp_main_en.pdf (accessed on 7 September 2020).

119. Werner, S. District heating and cooling in Sweden. Energy 2017, 126, 419-429. [CrossRef] 
120. District Energy in Sweden. Available online: https://www.euroheat.org/knowledge-hub/district-energy-sweden/ (accessed on 1 September 2020).

121. Söderholm, K. Pioneering industry/municipal district heating collaboration in Sweden in the 1970s. Energy Policy 2018, 112, 328-333. [CrossRef]

122. Börjesson, P.; Hansson, J.; Berndes, G. Future demand for forest-based biomass for energy purposes in Sweden. For. Ecol. Manag. 2017, 383, 17-26. [CrossRef]

123. Savvidou, G.; Nykvist, B. Heat demand in the Swedish residential building stock-Pathways on demand reduction potential based on socio-technical analysis. Energy Policy 2020, 144. [CrossRef]

124. District Energy in Finland. Available online: https://www.euroheat.org/knowledge-hub/district-energy-finland/ (accessed on 1 September 2020).

125. Energy Sector in Finland. Available online: https://energia.fi/en/energy_sector_in_finland/energy_networks/district_heating networks (accessed on 1 September 2020).

126. District Heating. Available online: http://gebwell.fi/en/district-heating/ (accessed on 2 September 2020).

127. The Act Banning the Use of Coal for Energy Generation in 2029 to Enter into Force in Early April. Available online: https://valtioneuvosto.fi/en/-/1410877/kivihiilen-energiakayton-vuonna-2029-kieltava-laki-voimaan-huhtikuun-alussa?_1 01_INSTANCE_YZfcyWxQB2Me_languageId=en_US (accessed on 2 September 2020).

128. Todorov, O.; Alanne, K.; Virtanen, M.; Kosonen, R. Aquifer thermal energy storage (ATES) for district heating and cooling: A novel modeling approach applied in a case study of a Finnish urban district. Energies 2020, 13, 2478. [CrossRef]

129. Abdurafikov, R.; Grahn, E.; Kannari, L.; Ypyä, J.; Kaukonen, S.; Heimonen, I.; Paiho, S. An analysis of heating energy scenarios of a Finnish case district. Sustain. Cities Soc. 2017, 32, 56-66. [CrossRef]

130. Kontu, K.; Rinne, S.; Junnila, S. Introducing modern heat pumps to existing district heating systems-Global lessons from viable decarbonizing of district heating in Finland. Energy 2019, 166, 862-870. [CrossRef]

131. Wahlroos, M.; Pärssinen, M.; Manner, J.; Syri, S. Utilizing data center waste heat in district heating-Impacts on energy efficiency and prospects for low-temperature district heating networks. Energy 2017, 140, 1228-1238. [CrossRef]

132. Värri, K.; Syri, S. The possible role of modular nuclear reactors in district heating: Case Helsinki region. Energies 2019, 12, 2195. [CrossRef]

133. Teräsvirta, A.; Syri, S.; Hiltunen, P. Small Nuclear Reactor-Nordic District Heating Case Study. Energies 2020, 13, 3782. [CrossRef]

134. Ur Rehman, H.; Hirvonen, J.; Sirén, K. A long-term performance analysis of three different configurations for community-sized solar heating systems in high latitudes. Renew. Energy 2017, 113, 479-493. [CrossRef]

135. Gehlin, S. Borehole Thermal Energy Storage. In Advances in Ground-Source Heat Pump System; Ress, S.J., Ed.; Woodhead Publishing (Elsevier): Cambridge, UK, 2016; pp. 295-327. [CrossRef]

136. Varnagirytė-Kabašinskienė, I.; Lukminè, D.; Mizaras, S.; Beniušienè, L.; Armolaitis, K. Lithuanian forest biomass resources: Legal, economic and ecological aspects of their use and potential. Energy. Sustain. Soc. 2019, 9, 1-19. [CrossRef]

137. Valancius, R.; Singh, R.M.; Jurelionis, A.; Vaiciunas, J. A review of heat pump systems and applications in cold climates: Evidence from Lithuania. Energies 2019, 12, 4331. [CrossRef]

138. District Energy in Lithuania. Available online: https://www.euroheat.org/knowledge-hub/district-energy-lithuania/ (accessed on 1 September 2020).

139. Jonkutè, G.; Norvaišienė, R.; Banionis, K.; Monstvilas, E.; Bliūdžius, R. Analysis of carbon dioxide emissions in residential buildings through energy performance certification in Lithuania. Energy Sources Part B Econ. Plan. Policy 2020, 1-18. [CrossRef]

140. Valancius, R.; Jurelionis, A.; Vaiciunas, J. Review of Solar Thermal Systems and Their Potential in Lithuania. In Proceedings of the International Conference on Solar Energy and Buildings, Palma de Mallorca, Spain, 11-14 October 2016; pp. 1-7. [CrossRef]

141. Valancius, R.; Cerneckiene, J.; Singh, R.M. Review of Combined Solar Thermal and Heat Pump Systems Installations in Lithuanian Hospitals. In Proceedings of the EuroSun 2018 Conference of ISES Europe, Rapperswil, Switzerland, 10-13 September 2018. [CrossRef]

142. Geothermal Energy Use, Country Update for Sweden. Available online: http://europeangeothermalcongress.eu/wp-content/ uploads /2019/07/CUR-28-Sweden.pdf (accessed on 30 October 2020).

143. National Energy Independence Strategy Executive Summary-Energy for Competitive Lithuania. Available online: https:/ / enmin. lrv.lt/uploads/enmin/documents/files/National_energy_independence_strategy_2018.pdf (accessed on 1 September 2020).

144. Kveselis, V.; Dzenajavičienè, E.F.; Masaitis, S. Analysis of energy development sustainability: The example of the lithuanian district heating sector. Energy Policy 2017, 100, 227-236. [CrossRef]

145. Šiupšinskas, G.; Rogoža, A. Modernisation of the existing energy supply system to CO2 neutral system: Lithuanian town case study. In Proceedings of the International Conference on Environmental Engineering, ICEE 2014, Vilnius, Lithuania, 22-24 May 2014. [CrossRef]

146. Krikser, T.; Profeta, A.; Grimm, S.; Huther, H. Willingness-to-Pay for District Heating from Renewables of Private Households in Germany. Sustainability 2020, 12, 4129. [CrossRef]

147. District Energy in Germany. Available online: https://www.euroheat.org/knowledge-hub/district-energy-germany/ (accessed on 1 September 2020).

148. Weinand, J.M.; Kleinebrahm, M.; McKenna, R.; Mainzer, K.; Fichtner, W. Developing a combinatorial optimisation approach to design district heating networks based on deep geothermal energy. Appl. Energy 2019, 251, 113367. [CrossRef] 
149. Petersen, J.P. Energy concepts for self-supplying communities based on local and renewable energy sources: A case study from northern Germany. Sustain. Cities Soc. 2016, 26, 1-8. [CrossRef]

150. Pelda, J.; Stelter, F.; Holler, S. Potential of integrating industrial waste heat and solar thermal energy into district heating networks in Germany. Energy 2020, 203. [CrossRef]

151. Shrestha, N.L.; Urbaneck, T.; Oppelt, T.; Platzer, B.; Göschel, T.; Uhlig, U.; Frey, H. Implementation of large solar thermal system into district heating network in Chemnitz (Germany). ISES Sol. World Conf. 2017, 322-332. [CrossRef]

152. Schüppler, S.; Fleuchaus, P.; Blum, P. Techno-economic and environmental analysis of an Aquifer Thermal Energy Storage (ATES) in Germany. Geotherm. Energy 2019, 7. [CrossRef]

153. District Energy in Latvia. Available online: https://www.euroheat.org/knowledge-hub/district-energy-latvia/ (accessed on 5 September 2020).

154. Latvian City Invests in Solar District Heating. Available online: https:/ /www.euroheat.org/knowledge-hub/latvian-city-investssolar-district-heating/ (accessed on 5 September 2020).

155. Kamenders, A.; Vilcane, L.; Indzere, Z.; Blumberga, D. Heat Demand and Energy Resources Balance Change in Latvia. Energy Procedia 2017, 113, 411-416. [CrossRef]

156. National Energy and Climate Plan of Latvia 2021-2030. Available online: https://ec.europa.eu/energy/sites/ener/files/ documents/ec_courtesy_translation_lv_necp.pdf (accessed on 7 September 2020).

157. Latvian DH Share. Available online: https://www.euroheat.org/knowledge-hub/district-energy-austria/attachment/latvia-dhshare/ (accessed on 7 September 2020).

158. Povilanskas, R.; Satkūnas, J.; Jurkus, E. Conditions for deep geothermal energy utilisation in southwest Latvia: Nīca case study. Baltica 2013, 26, 193-200. [CrossRef]

159. Ziemele, J.; Gravelsins, A.; Blumberga, A.; Blumberga, D. Combining energy efficiency at source and at consumer to reach 4th generation district heating: Economic and system dynamics analysis. Energy 2017, 137, 595-606. [CrossRef]

160. Ziemele, J.; Gravelsins, A.; Blumberga, A.; Vigants, G.; Blumberga, D. System dynamics model analysis of pathway to 4th generation district heating in Latvia. Energy 2016, 110, 85-94. [CrossRef]

161. Feofilovs, M.; Pakere, I.; Romagnoli, F. Life Cycle Assessment of Different Low-Temperature District Heating Development Scenarios: A Case Study of Municipality in Latvia. Environ. Clim. Technol. 2019, 23, 272-290. [CrossRef]

162. Cirule, D.; Pakere, I.; Blumberga, D. Legislative Framework for Sustainable Development of the 4th Generation District Heating System. Energy Procedia 2016, 95, 344-350. [CrossRef]

163. Low Temperature District Heating for the Baltic Sea Region. Available online: https://projects.interreg-baltic.eu/projects/ lowtemp-112.html (accessed on 12 September 2020).

164. BSAM-Baltic Smart Asset Management. Available online: https:/ / southbaltic.eu/- /bsam (accessed on 12 September 2020).

165. Heat Roadmap Europe. Available online: https:/ / heatroadmap.eu/ (accessed on 12 September 2020).

166. Innovative Technology for District Heating and Cooling. Available online: https://cordis.europa.eu/project/id/696174/pl (accessed on 13 September 2020).

167. REnewable Low TEmperature District. Available online: https://cordis.europa.eu/project/id/768567/pl (accessed on 13 September 2020).

168. THERMOS (Thermal Energy Resource Modelling and Optimisation System). Available online: https://cordis.europa.eu/project/ id/723636 (accessed on 13 September 2020).

169. TEMPerature Optimisation for Low Temperature District Heating across Europe. Available online: https: / / cordis.europa.eu/ project/id/768936/pl (accessed on 14 September 2020).

170. Smart and Local Renewable Energy DISTRICT Heating and Cooling Solutions for Sustainable Living. Available online: https: / / cordis.europa.eu/project/id/857801 (accessed on 14 September 2020).

171. Recovery of Urban Excess Heat. Available online: https://cordis.europa.eu/project/id/767429/pl (accessed on 15 September 2020).

172. Cool Ways of Using Low Grade Heat Sources from Cooling and Surplus Heat for Heating of Energy Efficient Buildings with New Low Temperature District Heating (LTDH) Solutions. Available online: https://cordis.europa.eu/project/id/767799 (accessed on 13 September 2020).

173. Improving the Performance of District Heating Systems in Central and East Europe. Available online: https: / cordis.europa.eu/ project/id/784966 (accessed on 20 September 2020). 